\title{
Long-term effects and cost-benefit analysis of eight spawning gravel augmentations for Atlantic salmon and Brown trout in Norway
}

\author{
Ulrich Pulg (1) - Robert J. Lennox • Sebastian Stranzl • Espen O. Espedal • \\ Sven Erik Gabrielsen - Tore Wiers - Gaute Velle - Christoph Hauer • \\ Bjørn Otto Dønnum • Bjørn T. Barlaup
}

Received: 10 March 2020/Revised: 28 April 2021/Accepted: 14 May 2021/Published online: 10 August 2021

(C) The Author(s) 2021

\begin{abstract}
River regulation alters flow and sediment regime, habitat availability, and ultimately the ecological functioning of rivers. Various restoration and mitigation measures have been developed to improve ecological function, and among them is the addition of gravel to enhance the reproduction of gravel bed spawning fishes. However, information on long-term efficiency, costs, and maintenance needs of gravel additions are scarce. Here, we study the functioning of gravel additions at eight sites in three rivers in western Norway for up to 18 years. Gravel was added between 2002 and 2010 to enhance spawning of Atlantic salmon and anadromous Brown trout. We monitored changes in the size of the gravel-covered areas, sediment composition, interstitial oxygen, egg survival, and juvenile fish
\end{abstract}

Guest editors: Ingeborg P. Helland, Michael Power, Eduardo G. Martins \& Knut Alfredsen / Perspectives on the environmental implications of sustainable hydro-power

U. Pulg $(\varangle) \cdot$ R. J. Lennox $\cdot$ S. Stranzl ·

E. O. Espedal · S. E. Gabrielsen · T. Wiers ·

G. Velle · B. T. Barlaup

Norwegian Research Center (NORCE), LFI,

Nygårdsgaten 112, 5008 Bergen, Norway

e-mail: ulrich.pulg@uni.no

C. Hauer

Christian Doppler Laboratory for Sediment Research and Management, Institute of Water Management, Hydrology and Hydraulic Engineering, Department of Water, Atmosphere and Environment, University of Natural Resources and Life Sciences, Vienna, Muthgasse 107, 1190 Vienna, Austria densities. Additionally, we report monetary costs, identify potential maintenance needs, and calculate a cost-benefit ratio. Juvenile densities of Atlantic salmon and Brown trout increased significantly after the gravel augmentations. After 10-18 years, the median egg survival was still high $(>90 \%)$ and sediment conditions were still suitable for salmonid fish reproduction. The areas were, however, shrinking across time (median area reduction 26\%), mostly caused by scouring of gravel in the steep, supply-limited, and partly regulated rivers. The average construction costs of spawning gravel augmentations were 11.2 NOK $(1.12 €) \mathrm{m}^{-2}$ year $^{-1}$. Compared to similar measures elsewhere, the measures have had a long life span (up to 18 years) at relatively low costs. Gravel augmentation was concluded to be a successful management measure that contributed to significantly increased Atlantic salmon and Brown trout reproduction.

\author{
B. O. Dønnum \\ Hafslund E-CO Vannkraft, CJ Hambros Plass 2c, \\ 0104 Oslo, Norway
}


Keywords Restoration - Mitigation - Enhancement . Spawning $\cdot$ Sediment $\cdot$ Habitat

\section{Introduction}

Brown trout (Salmo trutta Linnaeus, 1758) and Atlantic salmon (Salmo salar, Linnaeus, 1758) are gravel bed spawners, similar to many other rheophilic fishes of the northern Hemisphere (Jungwirth et al., 2000; Klemetsen et al., 2003). The species are nest builders that dig spawning redds into gravel substrate where eggs are fertilized and then buried by the fish. Characteristic spawning habitats are found in glides, often between runs or pools, and riffles on gravel sediments (grain size range 5-100 mm). Water depth at these sites during median discharge is usually $0.1-1 \mathrm{~m}$ and water velocity 0.1 to $0.6 \mathrm{~m} \mathrm{~s}^{-1}$ for both Atlantic salmon and Brown trout (Klemetsen et al., 2003; Barlaup et al., 2008; Louhi et al., 2008). As interstitial spawners (Pulg, 2009), the species depend on loose and clean gravel to provide sufficient interstitial water supply. The eggs usually need 2 to 5 months to develop in the interstitial spaces, depending on temperature (Barlaup et al., 2008; Louhi et al., 2008; Pulg, 2009). Eggs require average interstitial $\mathrm{O}_{2}$ concentrations $\left(\mathrm{IO}_{2}\right)$ larger than $6.7 \mathrm{mg} \mathrm{l}^{-1}$, average grain size diameters $(\mathrm{Dg})$ larger than $5.7 \mathrm{~mm}$, and percentage fine sediment $(\mathrm{PF},<1$ $\mathrm{mm}$ grain size) lower than $18.5 \%$. High egg-to-fry survival $(50-100 \%)$ is correlated with $\mathrm{IO}_{2}$ of at least $10.4 \mathrm{mg} \mathrm{l}^{-1}, \mathrm{Dg}$ of at least $12.9 \mathrm{~mm}$ and $\mathrm{PF}$ of maximum 10.3\% (Pulg et al., 2013).

Lack of spawning habitats in regulated rivers is considered a main driver of the decline of gravel bed spawning fishes (Sear \& DeVries, 2008a; Hauer et al., 2018a, b). River regulation may cause reduced gravel supply by blocking gravel transport from upstream reaches with physical barriers, but also by increasing transport capacity (scouring) or in the opposite, by reducing flood dynamics (reduced turnover and lacking renewal of substrate, Barlaup et al., 2008; Pulg et al., 2013). Bank stabilization, riprap, development of infrastructure in the floodplain, and other measures will reduce lateral gravel input that replaces sediments transported downstream by floods (Hauer et al., 2018a), resulting in net losses of spawning habitat and shrinking of the area suitable for gravel bed spawning. Surplus of fine sediments (grain size $<1$ $\mathrm{mm}$ ) infiltrating the gravel and clogging pore space often cause a degradation of spawning habitats. Water and oxygen supply of eggs and alevins are interrupted, leading to high mortality (Soulsby et al., 2001; Greig et al., 2007; Pulg et al., 2013). Increased fine sediment accumulation can be caused by river regulation, e.g. dams and impoundments. It is accelerated by erosive land use and input of fines (Opperman et al., 2005; Pulg, 2009; Pulg et al., 2013; Hauer et al., 2018a). In western Norway, however, the supply of fine sediments in non-glacial river catchments is comparatively limited with typically $<15 \mathrm{t} \mathrm{km}^{-2}$ per year (Bogen, 2015) compared to e.g. 250-1000 $\mathrm{t} \mathrm{km}^{-2}$ annually in the Alps or the Rocky Mountains (Walling \& Webb, 1996; Hauer \& Pulg, 2018). Due to thin soil cover and low percentage of agricultural land use $(<3 \%)$ the deposition of fine sediments in rivers is often considered of minor importance for spawning success, even at low flow velocities (Barlaup et al., 2008). The occurrence and distribution of salmonid spawning habitat is rather dependent on gravel supply, gravel stability, and scouring rate (Hauer et al., 2020).

Negative impacts of river regulation on spawning gravel supply and dynamics can be offset by gravel augmentation. Spawning gravel augmentation has become widely spread in Europe and North America as a mitigation measure in regulated rivers (Wheaton et al., 2004; Sear \& DeVries, 2008a; Barlaup et al., 2008; Pulg et al., 2019; Hauer et al., 2020; Staentzel et al., 2020). However, gravel augmentations often do not address the mechanisms underlying the decline and the availability of high-quality spawning habitats, such as dams and input of fines. Augmentations therefore have a limited life span depending on fine sediment load (Pulg et al., 2013), flood frequency, and magnitude (Merz et al., 2006). Strategies for resupplying gravel are not well developed because case studies on the effects of such gravel augmentations are usually limited to short periods of 1 to 5 years, if conducted at all, or ignore sediment monitoring (Sear \& DeVries, 2008a; Pedersen et al., 2009; Harrison et al., 2019). In a study on restored spawning sites in the USA, Chinook salmon (Oncorhynchus tshawytscha, Walbaum 1792) used the sites for spawning after 14 years, which to our knowledge is the only study that evaluates spawning habitats for longer than 10 years (Harrison et al., 2019). Hauer et al. (2020) documented a life span of spawning gravel addition of 
at least 5 years in Aurlandselva in Western Norway. Pulg et al. (2013) estimated that Brown trout spawning gravel was operational for 4 to 6 years in a German lowland stream (energy slope river 0.001; energy slope spawning ground 0.003-0.006). Pander et al. (2015) documented that their gravel augmentations were only operational as potential spawning habitat for 1 year in impounded German lowland streams.

River restoration should be based on natural fluvial processes because habitat enhancement methods have limited lifespans and need to be repeated (Hendry et al., 2003; Beechie et al., 2010). Thus, most gravel augmentation are rather management than restoration measures. Though not process based restoration, habitat enhancement techniques may contribute to attainment of environmental goals, such as an increase in total fish abundance or fish migration (Hauer et al., 2013; Roni, 2019). If applied properly, enhancement measures can function as intended and the limited life span can be handled by maintenance when necessary (e.g. repetition of gravel addition after some years) as is the case for many other man-made structures in regulated rivers (Hauer et al., 2013). While literature on long-term effects of restoration and habitat enhancement is scarce (Louhi et al., 2016; Staentzel et al., 2020), published data on costs of the projects are nearly non-existent. Only exceptionally costs are reported but then usually summed up for a variety of measures belonging to larger projects (Pedersen et al., 2007). There is a substantial knowledge gap on the link between costs and long-term effects of river restoration measures, even though such cost-benefit analyses should be essential to ecological policy. Ecological restoration is now included in policies worldwide, as underlined by the United Nations Decade On Ecosystem Restoration 2021-2030 (https://www.decadeonrestoration.org/, accessed February 19, 2020). In Europe, the Water Framework Directive has initiated habitat enhancements and billions of dollars are assumed to be spent on river restoration and habitat enhancement worldwide (Roni, 2019). There is a need for studies on the long-term effects of habitat enhancement measures, including their monetary costs and life span, to inform future efforts.

This study summarizes the extent to which eight gravel augmentations have functioned to restore salmonid spawning habitat in Norwegian rivers. It was hypothesized that they would improve sedimentologic spawning conditions and increase both salmonid egg survival and fry densities. It was predicted that the effect would decrease across time and it was aimed to measure the life span as well as the costs to estimate the maintenance needed to provide ongoing spawning possibilities. The analysis provides long-term data on the ecological effects and costs of such measures.

\section{Materials and methods}

Eight of the oldest known spawning gravel augmentation sites were studied in three Norwegian rivers. We measured the effect on the target fish species, anadromous Brown trout and Atlantic salmon, by sampling sediment quality, egg survival, and juvenile abundance (Barlaup et al., 2008; Pedersen et al., 2009; Pulg et al., 2013). Six sites were in River Aurlandselva, (Fig. 1, built in 2010), one in River Flekkeelva (built in 2005), and one in River Matreelva (built in 2002). Sampling was conducted at all six sites in Aurlandselva from 2010 to 2020; in Matreelva in 2002, 2003, 2006-2017 and 2020, in Flekkeekva 2006-2010 and 2018. The sampling and its timing are presented in detail in Table 2.

Study area

Western Norway's coastal streams and lakes are inhabited by mainly five fish species, Brown trout (Salmo trutta Linnaeus, 1758), Atlantic salmon (Salmo salar Linnaeus, 1758), Arctic char (Salvelinus alpinus Linnaeus, 1758), three-spined stickleback (Gasterosteus aculeatus Linnaeus, 1758), and European eel (Anguilla anguilla Linnaeus, 1758). Bedrock consists mainly of Caledonian gneisses, partly also phyllite, amphibolite, anorthosite, and Proterozoic granites. Recent tectonic dynamics are lacking. The post-glacial landscape has scoured bedrock valleys with low sediment supply and fluvial, semi-fluvial and non-fluvial river reaches (Hauer \& Pulg, 2018). Lakes occur in most watersheds, and there is a high morphological variation between river reaches, in contrast to fluvial rivers which typically have decreasing slope from source to sea (Kinghton, 1998; Vannote et al., 1980). Land use in the drainages of the rivers is characterized by small percentages of agriculture $(<1.7 \%)$ and little human settlement $(<0.1 \%)$. The 
drainages are dominated by forest (7-44\%), mountain tundra and exposed rock (36-77\%), as well as lakes (8-15\%) (www.nevina.nve.no, accessed September 29th 2020). The rivers are clear and likely to have low suspended loads (only data from Aurlandselva $<2 \mathrm{mg} \mathrm{l}^{-1}$, Ugedal et al., 2019).

The river Aurlandselva (Fig. 1) has a catchment area of $802 \mathrm{~km}^{2}$. The average energy slope of the study reach, the lowest $7.8 \mathrm{~km}$ between the river mouth and lake Vassbygvatnet is $0.0069(53.82 \mathrm{~m}$ drop at $7.8 \mathrm{~km}$ length). The discharge regime is heavily modified by hydropower regulation, with $75 \%$ of the annual precipitation being temporarily stored in reservoirs and directed through hydroplants (Væringstad, 2019). There is a minimum flow requirement in winter and summer of $3 \mathrm{~m}^{3} \mathrm{~s}^{-1}$ and 20 to $30 \mathrm{~m}^{3} \mathrm{~s}^{-1}$, respectively (Ugedal et al., 2019). Average flow (2010-2020) was $14.6 \mathrm{~m}^{3} \mathrm{~s}^{-1}$, while the average yearly flood estimate is $51 \mathrm{~m}^{3} \mathrm{~s}^{-1}$ (Table 1). During low flow conditions, the average water depth is $0.66 \mathrm{~m}$ and the mean channel width is $23.4 \mathrm{~m}$. The river exhibits morphological alterations, such as bank protection, groins, and a weir with fish pass at the outlet of lake Vassbygdvatnet. Sediment transport is not possible through lake Vassbygvatnet, thus the sediment continuum is naturally interrupted. Moreover, lateral gravel supply from glaciofluvial deposits is considered significantly reduced in the lower stretch due to reduced flood dynamics and bank protection measures along the lower river. Reduced spawning habitat was therefore identified as a bottleneck for reproduction of anadromous Brown trout and Atlantic salmon (Ugedal et al., 2019; Hauer et al., 2020).

Matreelva has a catchment area of $159 \mathrm{~km}^{2}$, an average flow after regulation (2002-2020) of 3.5 $\mathrm{m}^{3} \mathrm{~s}^{-1}$, and an average yearly flood estimate of 23 $\mathrm{m}^{3} \mathrm{~s}^{-1}$ (Fig. 2, Table 1). The average energy slope in the lower stretch $(4.7 \mathrm{~km})$ accessible for anadromous salmonids is 0.016 . A small lake of $0.5 \mathrm{~km}$ length is situated halfway between the mouth and the natural

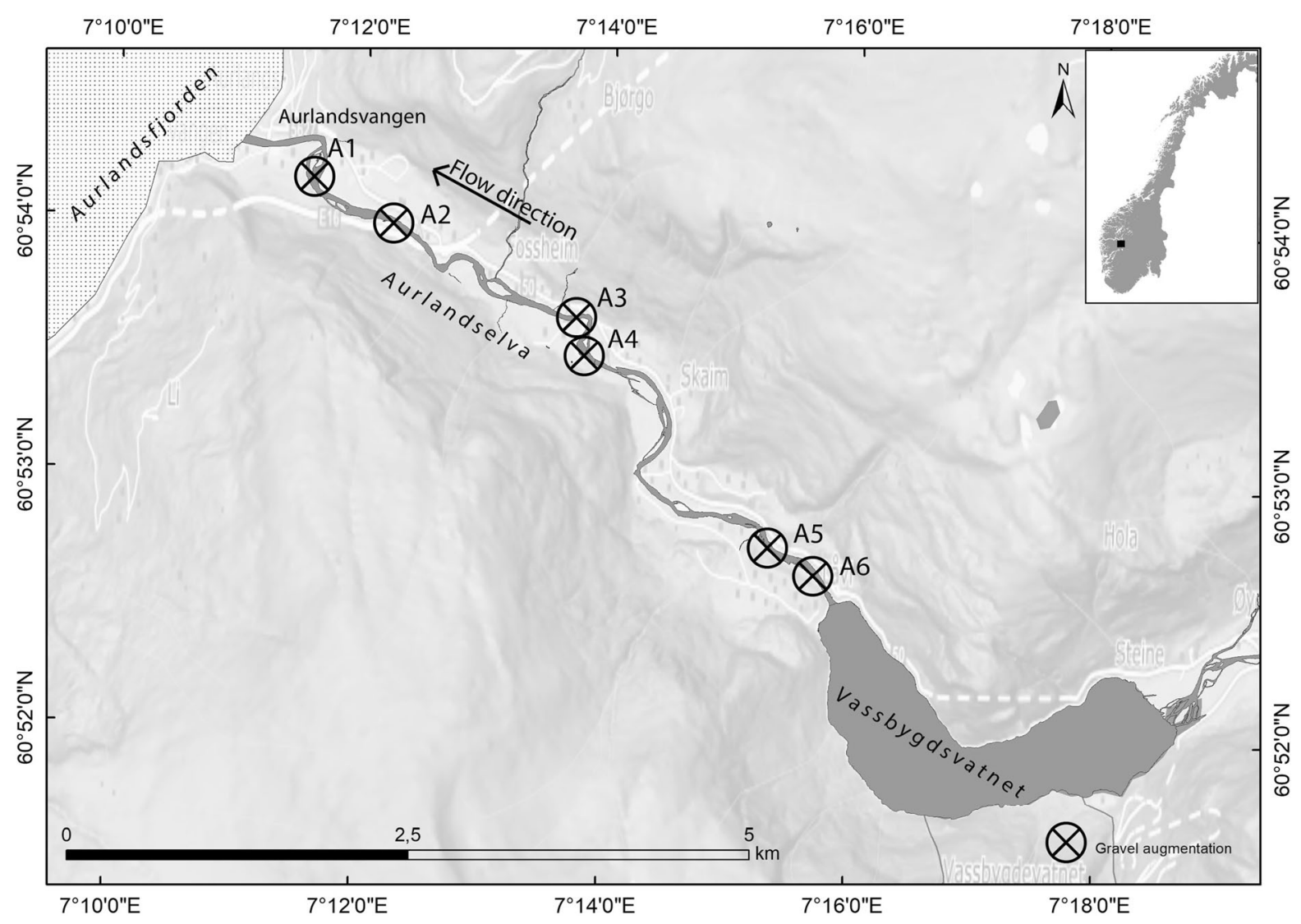

Fig. 1 Study area: River Aurlandselva and spawning gravel augmentation sites 
Table 1 Hydrological parameters for the three case rivers

\begin{tabular}{|c|c|c|c|c|c|c|}
\hline & \multicolumn{2}{|c|}{ Aurlandselva 2010-2020 } & \multicolumn{2}{|c|}{ Matreelva 2002-2020 } & \multicolumn{2}{|c|}{ Flekkeelva 2005-2020 } \\
\hline & $\begin{array}{l}\text { Discharge } \\
\left(\mathrm{m}^{3} \mathrm{~s}^{-1}\right)\end{array}$ & Nr. of flood events & $\begin{array}{l}\text { Discharge } \\
\left(\mathrm{m}^{3} \mathrm{~s}^{-1}\right)\end{array}$ & Nr. of flood events & $\begin{array}{l}\text { Discharge } \\
\left(\mathrm{m}^{3} \mathrm{~s}^{-1}\right)\end{array}$ & Nr. of flood events \\
\hline Q50 & 4.1 & & 1.9 & & 12.6 & \\
\hline QA & 14.6 & & 3.5 & & 22.5 & \\
\hline range & $2.0-143.6$ & & $0.04-119.41$ & & $0.5-325.3$ & \\
\hline $\mathrm{HQm}$ & 51 & 33 & 23 & 47 & 223 & 11 \\
\hline HQ5 & 92 & 3 & 70 & 2 & 278 & 4 \\
\hline HQ10 & 109 & 2 & 90 & 2 & 314 & 1 \\
\hline HQ20 & 127 & 1 & 110 & 1 & $360^{*}$ & 0 \\
\hline HQ50 & 149 & 0 & 137 & 0 & 383 & 0 \\
\hline
\end{tabular}

Median, average, and range of discharge and annual to 50-year flood events

$Q 50$ median discharge, $Q A$ average discharge, *interpolated

migration barrier. The flow regime is heavily modified by hydropower in the lowest $4.7 \mathrm{~km}$, with a $75 \%$ reduction of annual average flow which is paralleled through a hydroplant with a maximum discharge of 30 $\mathrm{m}^{3} \mathrm{~s}^{-1}$ (Gabrielsen et al. 2011). The power company discharges a voluntary residual flow of $0.2 \mathrm{~m}^{3} \mathrm{~s}^{-1}$ in the lower stretch of the river. During errors, discharge can drop lower (range $0.04-119.41 \mathrm{~m}^{3} \mathrm{~s}^{-1}$, Table 1). Parts of the riverbanks are stabilized by riprap enforcement and the upper quarter below the migration barrier lacks spawning areas (Gabrielsen et al. 2011).

Flekkeelva has a catchment area of $262 \mathrm{~km}^{2}$, an average flow (2005-2020) of $22.5 \mathrm{~m}^{3} \mathrm{~s}^{-1}$ and an average yearly flood estimate of $223 \mathrm{~m}^{3} \mathrm{~s}^{-1}$ (Fig. 3, Table 1). The flow regime is not modified by hydropower regulation, but there are minor bank enforcements in parts of the river. The average energy slope in the lower stretch $(8.2 \mathrm{~km})$ accessible for anadromous salmonids is 0.0024 . Three lakes dominate this stretch, with $6 \mathrm{~km}$ of $8.2 \mathrm{~km}$ in lakes. The hydrograph of the rivers is shown in Figs. 15, 16, and 17 and discharge parameters for the catchment are shown in Table 1 .

Flood indices and hydrology

Flow data and the recurring intervals of floods are used to evaluate the life span of the gravel augmentations. Annual flood (HQm) is defined as the average yearly maximum discharge, and e.g. HQx is a flood event with $\mathrm{x}$ years recurring interval. In order to reflect flow conditions after regulation in Aurlandselva and Matreelva we used Gumbel-distributions of the maximum annual discharge to calculate flood recurrence intervals after regulation, with discharge data provided by the hydropower companies for the last 30 years in Aurlandselva and the last 11 years in Matreelva. The discharge for the remaining time in Matreelva (2002-2009 and data gaps) was correlated to the nearest water gauge (Svartavatn, NVE nr. 62.18.0, approximately $30 \mathrm{~km}$ distance, linear regression $y=0.999+0.288 x, R 2=0.561)$. The gauges are correlated by 0.749 (Pearson correlation, Sig. 0.000).

In Flekkeelva, which is not regulated by hydropower we used the official flood calculations provided by the national water authority (https://www2.nve.no/ h/hd/plotreal/Q/0082.00004.000/, accessed September 28th, 2020), Only HQ20 was calculated by a Gumbel distribution. Flow charts are presented in Figs. 15, 16, and 17.

Fish and egg sampling

Electrofishing surveys were conducted in autumn (September-October) along the shore at the spawning gravel addition sites. They started at least the year before fry could hatch from the added gravel (Table 2). In Aurlandselva, the sites were sampled annually from 2010 to 2020. In Matreelva, the gravel augmentation site was fished annually from 2002 to 2005 and from 2008 to 2017. At Flekkeelva, fish sampling was conducted annually between 2004 and 


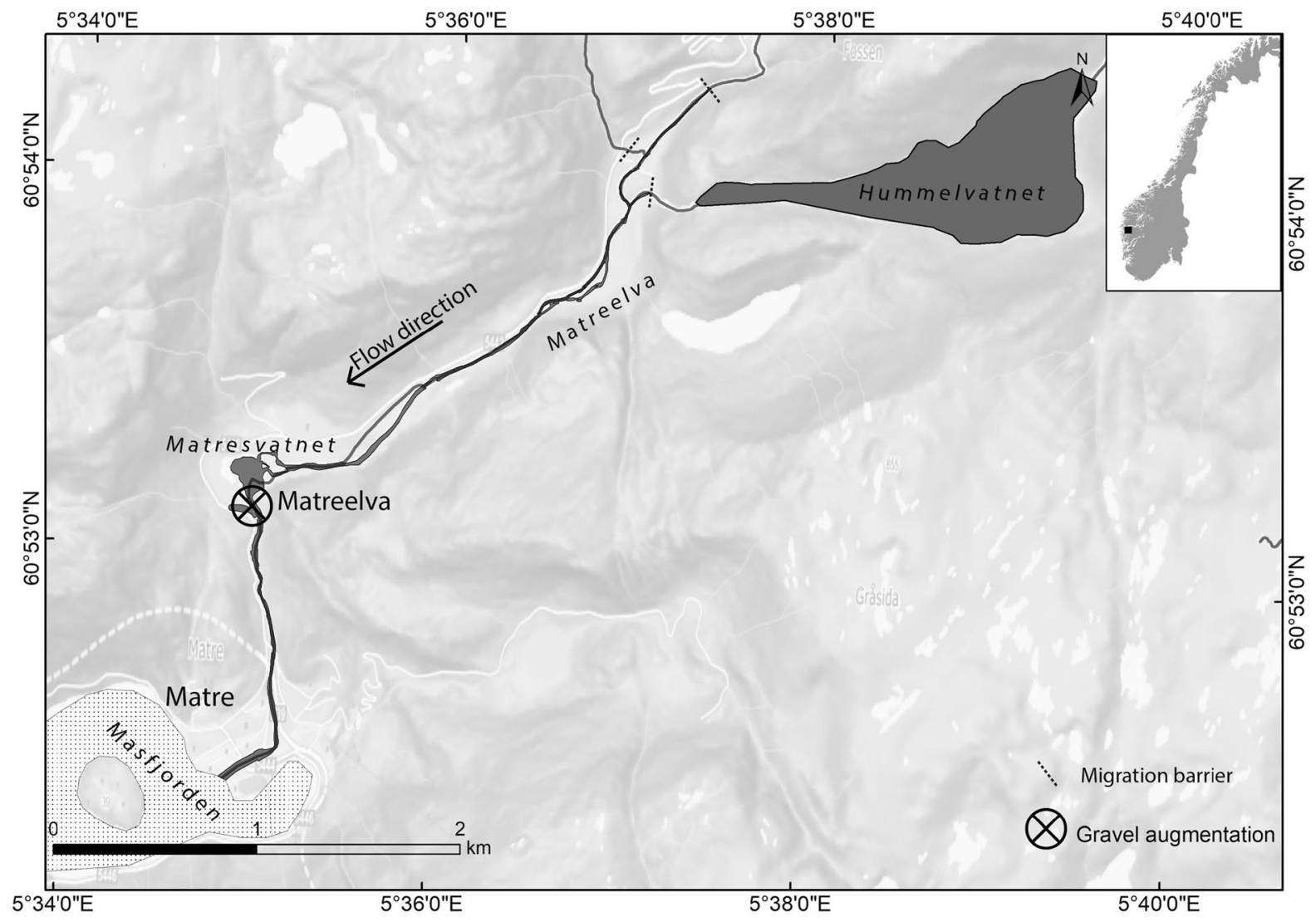

Fig. 2 Study area: River Matreelva and spawning gravel augmentation site

2010 and in 2018. The electrofishing was conducted with backpack electrofishing equipment on a singlepass longitudinal transect up to $4 \mathrm{~m}$ width and $50 \mathrm{~m}$ length and a total area of $100 \mathrm{~m}^{2}$ (Hedger et al., 2018, $1400 \mathrm{~V}$, DC, pulsed current, GeOmega A/S). The single-pass data were used for our data analysis. This protocol underestimates the true density, but provides a standard index to test for changes in juvenile density over time (Bohlin et al., 1989, 2006; Foldvik et al., 2017; Hedger et al., 2018).

Captured fish were identified to species, measured, and released alive. Age class was estimated from the length of the fish, allowing distinction of the age groups fry $(<7 \mathrm{~cm})$, considered to be $0+$ young of the year fish, and parr $(8-16 \mathrm{~cm})$, which could be 1 to 3 years old (Pulg et al., 2019). Fry densities were used to evaluate effects of the gravel augmentations because fry are relatively immobile and considered as good indicators for spawning (Teichert et al., 2011; Foldvik et al., 2017; Pulg et al., 2019). Juvenile anadromous Brown trout and Atlantic salmon in the region usually reach smolt age at $12-16 \mathrm{~cm}$ after 3 years in the rivers, and outmigrate in spring to feed on marine resources (Jonsson \& Jonsson, 2011; Jonsson et al., 2011). Egg survival was measured following Barlaup et al. (2008). Snorkelers searched the gravel for spawning redds in March when eggs were just before hatching or had hatched. Egg pockets were opened by carefully removing gravel and counting the visible subsample of living and dead eggs or alevins, before covering the pockets with gravel. Egg survival was measured in Matreelva 2002-2011 and 2018, in Flekkeelva 2018 and in Aurlandselva 2011-2019.

\section{Sediment quality and coverage}

$\mathrm{IO}_{2}, \mathrm{Dg}$ and PF were chosen as indicators of spawning sediment quality (Barlaup et al., 2008; Pulg et al., 2013). $\mathrm{IO}_{2}$ was measured in situ by applying a Terhune standpipe at a sediment depth of $0.15 \mathrm{~m}$ in the spawning gravel and a WTW 3440i multimeter 


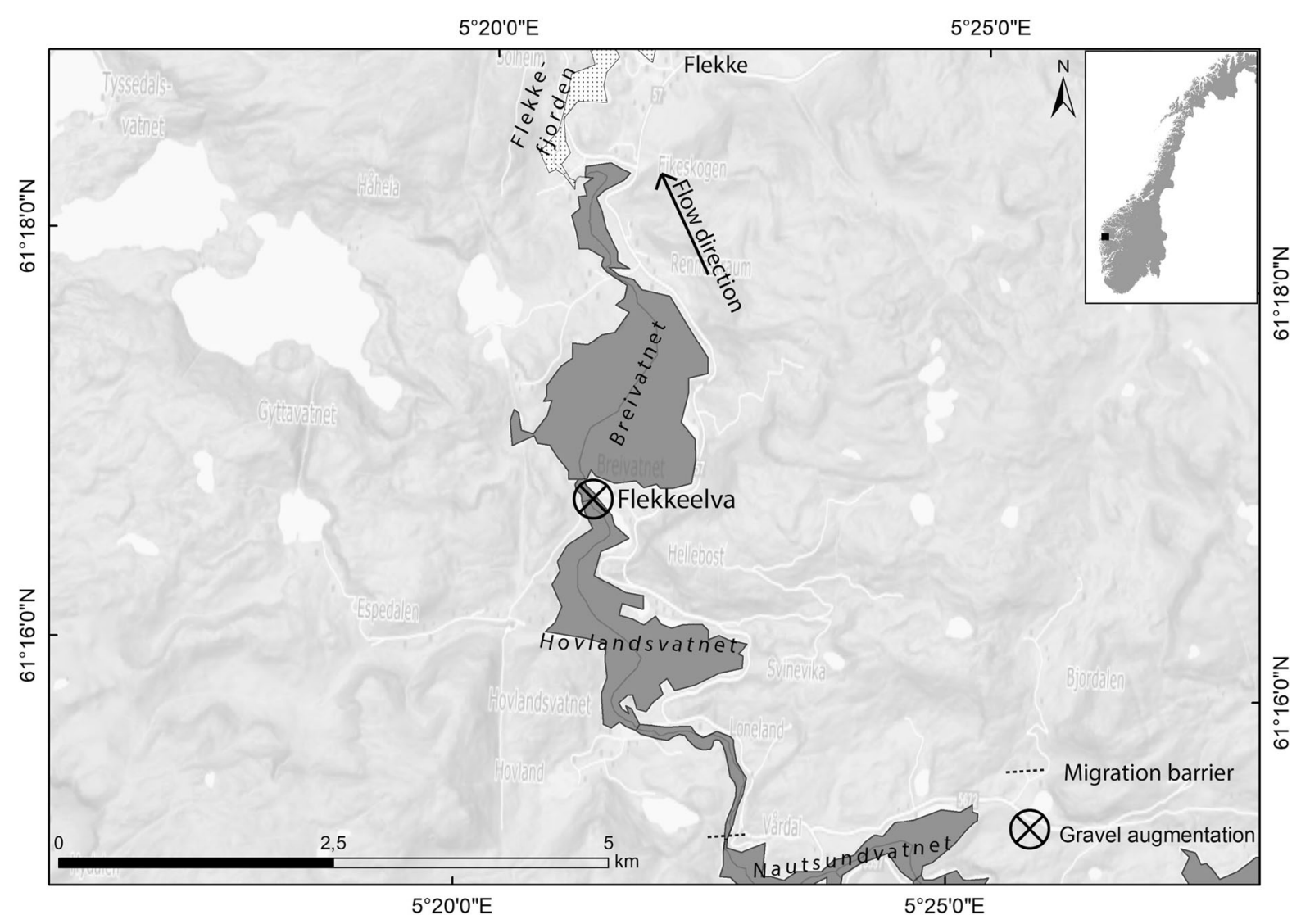

Fig. 3 Study area: River Flekkelva and spawning gravel augmentation site

(Terhune, 1958; Barlaup et al., 2008). For sediment sampling, the upper $15 \mathrm{~cm}$ of the sediment was shoveled into a submersed bag made of $150 \mu \mathrm{m}$ nylon netting, and sieved using mesh sizes 1, 2, 4, 8, 16, 32, 64 and $128 \mathrm{~mm}$ (Barlaup et al., 2008). About $33 \mathrm{~kg}$ of dry sediments were sampled on each occasion in Matre- and Flekkeelva. Dg was calculated following Rubin \& Glimsaeter (1996). The grain size distribution curve in Matreelva 2002 and Flekkeelva 2005 were provided by the gravel mining operators delivering the applied sediments. In Aurlandselva, $10.1 \mathrm{~kg}$ of the original gravel was sieved in 2010 and one sediment sample was taken on each spawning site 2018 (6.9 to $12.3 \mathrm{~kg}$ ).

The area covered by the added gravel was measured with a handheld differential RTK GPS (Trimble T3; horizontal precision $2 \mathrm{~cm} /$ vertical precision $5 \mathrm{~cm}$ ). After 2015, area was measured from orthophotos provided by Statens kartverk (norgeibilder.no, accessed 25.2.2020, $10 \mathrm{~cm}$ accuracy) and digitized georeferenced UAV aerial pictures (DJI Mavic 2 Pro, Esri ArcGIS 10.5, Agisoft Metashape Pro, $4 \mathrm{~cm}$ accuracy).

\section{Gravel addition design}

All sites with gravel augmentations were carefully chosen after mapping the river for sufficient morphologic and hydraulic conditions. In all cases, the gravel was placed in glides with lower energy slope (reach drop devided by reach length, see Fig.4) than the average slope of the river (Figs. 1, 2, 3). In Matre- and Flekkeelva, the glides were situated at lake outlets, whereas in Aurlandselva the sites were situated in the river. The design followed recommendations of Barlaup et al. (2008) and Pulg et al. (2013) using sieved gravel between 16 and $128 \mathrm{~mm}$, placed by an excavator and a dump truck (Fig. 4).

In Aurlandselva, $150 \mathrm{~m}^{3}$ of gravel were introduced in 2010. The gravel had a Dg of $37 \mathrm{~mm}$ and $0.01 \%$ 
Table 2 Biotic and abiotic data of the gravel augmentation sites in chronological order

\begin{tabular}{|c|c|c|c|c|c|c|c|c|c|}
\hline Year site & $\begin{array}{l}\text { Salmon fry } \\
{\left[\text { ind. } \mathrm{m}^{-1}\right]}\end{array}$ & $\begin{array}{l}\text { Salmon parr } \\
\text { [ind. } \mathrm{m}^{-1} \text { ] }\end{array}$ & $\begin{array}{l}\text { Trout fry } \\
\text { [ind. } \mathrm{m}^{-1} \text { ] }\end{array}$ & $\begin{array}{l}\text { Trout parr } \\
{\left[\text { ind. } \mathrm{m}^{-1} \text { ] }\right.}\end{array}$ & $\begin{array}{l}\text { Egg survival } \\
\text { [average \%] }\end{array}$ & $\begin{array}{l}\text { Spawning area } \\
{\left[\mathrm{m}^{2}\right]}\end{array}$ & $\begin{array}{l}\mathrm{IO}_{2} \\
{\left[\mathrm{mg} \mathrm{l}^{-1}\right]}\end{array}$ & $\begin{array}{l}\mathrm{DG} \\
{[\mathrm{mm}]}\end{array}$ & $\begin{array}{l}\mathrm{PF} \\
{[\%]}\end{array}$ \\
\hline 2002 Flekke & 26.8 & 4 & 21 & 1 & & & & & \\
\hline 2003 Flekke & 17.6 & 8.1 & 7 & 0 & & & & & \\
\hline 2002 Matre & 1 & 0 & 5 & 32.2 & & 271 & 12.2 & 32.2 & 0 \\
\hline 2003 Matre & 0 & 1 & 30 & 22.7 & 93.2 & & & & \\
\hline 2004 Flekke & 7.6 & 2.2 & 3 & 6.1 & & & & & \\
\hline 2005 Flekke & 58.2 & 7 & 0 & 3 & & 500 & & 37 & 0 \\
\hline 2005 Matre & & & & & 93.5 & & & & \\
\hline 2006 Flekke & 30 & 15.7 & 0 & 0 & & & & & \\
\hline 2006 Matre & & & & & 91.3 & & & & \\
\hline 2007 Flekke & 22 & 11 & 4 & 1 & & & & & \\
\hline 2007 Matre & & & & & 86.9 & & & & \\
\hline 2008 Flekke & 17 & 25.2 & 5.2 & 5 & & & & & \\
\hline 2008 Matre & 0 & 7 & 5 & 45.6 & 90.9 & & & & \\
\hline 2009 Flekke & 56 & 22.7 & 5.2 & 2 & & & & & \\
\hline 2009 Matre & 0 & 3 & 9.1 & 43.3 & 94.4 & & & & \\
\hline 2010 A1 & 2 & 0 & 30 & 16 & & 120 & & 37 & 0.01 \\
\hline 2010 A2 & 0 & 0 & 48 & 8 & & 42 & & 37 & 0.01 \\
\hline 2010 A3 & 0 & 0 & 46 & 14 & & 336 & & 37 & 0.01 \\
\hline 2010 A4 & 0 & 2 & 42 & 18 & & 196 & & 37 & 0.01 \\
\hline 2010 A5 & 8 & 8 & 14 & 2 & & 261 & & 37 & 0.01 \\
\hline 2010 A6 & 20 & 6 & 16 & 0 & & 68 & & 37 & 0.01 \\
\hline 2010 Matre & 0 & 4 & 40 & 58 & 89.8 & & & & \\
\hline 2010 Flekke & 26.9 & 7.4 & 3.1 & 7.1 & & & & & \\
\hline 2011 A1 & 6 & 0 & 36 & 10 & 63.0 & 122 & 13 & & \\
\hline 2011 A2 & 2 & 0 & 44 & 2 & 100.0 & 40 & 13.5 & & \\
\hline 2011 A3 & 2 & 0 & 62 & 4 & 100.0 & 340 & 13.2 & & \\
\hline 2011 A4 & 4 & 4 & 40 & 16 & 73.1 & 175 & 12.9 & & \\
\hline 2011 A5 & 18 & 10 & 34 & 6 & 83.0 & 285 & 113.1 & & \\
\hline 2011 A6 & 0 & 34 & 20 & 0 & 61.0 & 68 & 13.1 & & \\
\hline 2011 Matre & 1 & 6 & 14.8 & 72.7 & 89.6 & & & & \\
\hline 2012 A1 & 0 & 0 & 130 & 18 & 91.1 & 110 & 14 & & \\
\hline 2012 A2 & 4 & 0 & 50 & 20 & 92.5 & 39 & 14.1 & & \\
\hline 2012 A3 & 6 & 4 & 34 & 32 & 95.1 & 334 & 13.9 & & \\
\hline 2012 A4 & 0 & 5 & 66 & 28 & 93.6 & 177 & 13.9 & & \\
\hline 2012 A5 & 26 & 42 & 58 & 14 & 94.8 & 278 & 13.7 & & \\
\hline 2012 A6 & 9 & 12 & 27 & 12 & 70.7 & 65 & 13.3 & & \\
\hline 2012 Matre & 5 & 0 & 14 & 20 & & & & & \\
\hline 2013 A1 & 6 & 4 & 118 & 30 & 79.5 & 98 & 14.4 & & \\
\hline 2013 A2 & 7 & 5 & 50 & 23 & 78.8 & 38 & 15.5 & & \\
\hline 2013 A3 & 10 & 10 & 64 & 23 & 96.0 & 339 & 14.4 & & \\
\hline 2013 A4 & 0 & 3 & 105 & 53 & 94.8 & 174 & 14.3 & & \\
\hline 2013 A5 & 0 & 20 & 68 & 24 & 96.3 & 274 & 14 & & \\
\hline 2013 A6 & 4 & 10 & 52 & 10 & 63.3 & 64 & 14.1 & & \\
\hline 2013 Matre & 6.2 & 8 & 24 & 76 & & & & & \\
\hline
\end{tabular}


Table 2 continued

\begin{tabular}{|c|c|c|c|c|c|c|c|c|c|}
\hline Year site & $\begin{array}{l}\text { Salmon fry } \\
{\left[\text { ind. } \mathrm{m}^{-1}\right]}\end{array}$ & $\begin{array}{l}\text { Salmon parr } \\
{\left[\text { ind. } \mathrm{m}^{-1}\right]}\end{array}$ & $\begin{array}{l}\text { Trout fry } \\
{\left[\text { ind. } \mathrm{m}^{-1}\right]}\end{array}$ & $\begin{array}{l}\text { Trout parr } \\
{\left[\text { ind. }{ }^{-1}\right]}\end{array}$ & $\begin{array}{l}\text { Egg survival } \\
\text { [average \%] }\end{array}$ & $\begin{array}{l}\text { Spawning area } \\
{\left[\mathrm{m}^{2}\right]}\end{array}$ & $\begin{array}{l}\mathrm{IO}_{2} \\
{\left[\mathrm{mg} \mathrm{l}^{-1}\right]}\end{array}$ & $\begin{array}{l}\mathrm{DG} \\
{[\mathrm{mm}]}\end{array}$ & $\begin{array}{l}\mathrm{PF} \\
{[\%]}\end{array}$ \\
\hline 2014 A1 & 19 & 8 & 120 & 35 & 69.9 & 98 & 13.9 & & \\
\hline 2014 A2 & 14 & 9 & 55 & 24 & 92.6 & 24 & 13.8 & & \\
\hline 2014 A3 & 0 & 13 & 45 & 33 & 94.4 & 291 & 13.6 & & \\
\hline 2014 A4 & 0 & 4 & 70 & 62 & 95.8 & 115 & 13.2 & & \\
\hline 2014 A5 & 0 & 20 & 50 & 35 & 96.7 & 210 & 13.7 & & \\
\hline 2014 A6 & 4 & 10 & 40 & 30 & 84.4 & 45 & 12.9 & & \\
\hline 2014 Matre & 2 & 14 & 20 & 56 & & & & & \\
\hline 2015 A1 & 32 & 6 & 73 & 35 & 84.4 & 100 & 14.8 & & \\
\hline 2015 A2 & 25 & 2 & 45 & 32 & 96.9 & 20 & 14.9 & & \\
\hline 2015 A3 & 18 & 6 & 25 & 75 & 98.5 & 291 & 14.8 & & \\
\hline 2015 A4 & 9 & 4 & 65 & 69 & 100.0 & 114 & 14.6 & & \\
\hline 2015 A5 & 33 & 8 & 61 & 35 & 96.4 & 203 & 14.4 & & \\
\hline 2015 A6 & 37 & 5 & 65 & 27 & 91.7 & 45 & 14.6 & & \\
\hline 2015 Matre & 0 & 26 & 22 & 44 & & & & & \\
\hline 2016 A1 & 0 & 0 & 106 & 22 & 76.5 & 95 & 14.4 & & \\
\hline 2016 A2 & 20 & 22 & 46 & 76 & 94.0 & 1 & 14.4 & & \\
\hline 2016 A3 & 14 & 12 & 62 & 44 & 95.7 & 286 & 14 & & \\
\hline 2016 A4 & 2 & 0 & 31 & 71 & 80.6 & 94 & 13.9 & & \\
\hline 2016 A5 & 31 & 12 & 41 & 29 & 78.0 & 195 & 13.9 & & \\
\hline 2016 A6 & 19 & 21 & 36 & 43 & 95.2 & 43 & 13.1 & & \\
\hline 2016 Matre & 2 & 2 & 34 & 38 & & & & & \\
\hline 2017 A1 & 0 & 1 & 183 & 59 & 97.8 & 93 & 14.2 & & \\
\hline 2017 A2 & 2 & 11 & 79 & 48 & 98.8 & 1 & 14.4 & & \\
\hline 2017 A3 & 0 & 18 & 41 & 29 & 93.4 & 259 & 14.4 & & \\
\hline 2017 A4 & 0 & 11 & 25 & 78 & 88.9 & 92 & 14 & & \\
\hline 2017 A5 & 4 & 20 & 70 & 38 & 97.3 & 195 & 13.9 & & \\
\hline 2017 A6 & 0 & 20 & 18 & 32 & 83.9 & 43 & 13.5 & & \\
\hline 2017 Matre & 24 & 37.4 & 28.2 & 112.8 & & & & & \\
\hline 2018 A1 & 0 & 26 & 40 & 32 & 94.7 & 93 & 14.33 & & \\
\hline 2018 A2 & 16 & 21 & 56 & 43 & 88.1 & 1 & 14.43 & & \\
\hline 2018 A3 & 0 & 11 & 53 & 15 & 81.1 & 259 & 14.43 & & \\
\hline 2018 A4 & 6 & 14 & 64 & 54 & 86.8 & 92 & 14.16 & & \\
\hline 2018 A5 & 0 & 12 & 90 & 32 & 95.5 & 195 & 13.99 & & \\
\hline 2018 A6 & 0 & 0 & 184 & 22 & 92.8 & 43 & 13.1 & & \\
\hline 2018 Matre & & & & & 83.0 & 195 & 10.8 & & \\
\hline 2018 Flekke & 20 & 14 & 1 & 4 & 93.9 & 485 & 12.8 & 29.6 & 0.02 \\
\hline 2019 A1 & 1 & 3 & 120 & 58 & 98.0 & & 14.1 & 25.2 & 4.5 \\
\hline 2019 A2 & 0 & 4 & 78 & 59 & 100.0 & & 14.2 & 26.2 & 3.2 \\
\hline 2019 A3 & 1 & 4 & 64 & 62 & 87.6 & & 14.1 & 27.7 & 0.1 \\
\hline 2019 A4 & 1 & 11 & 57 & 71 & 80.0 & & 14 & 40 & 0.03 \\
\hline 2019 A5 & 6 & 16 & 83 & 44 & 100.0 & & 13.9 & 37.2 & 0.07 \\
\hline 2019 A6 & 40 & 10 & 16 & 14 & 98.1 & & 14 & 32.4 & 0.04 \\
\hline 2019 Matre & & & & & & & & 12.8 & 10.4 \\
\hline 2020 A1 & 0 & 30 & 36 & 22 & 93.4 & & 14.4 & 32.9 & 3.2 \\
\hline
\end{tabular}


Table 2 continued

\begin{tabular}{|c|c|c|c|c|c|c|c|c|c|}
\hline Year site & $\begin{array}{l}\text { Salmon fry } \\
{\left[\text { ind. } \mathrm{m}^{-1}\right]}\end{array}$ & $\begin{array}{l}\text { Salmon parr } \\
{\left[\text { ind. }{ }^{-1}\right]}\end{array}$ & $\begin{array}{l}\text { Trout fry } \\
{\left[\text { ind. } \mathrm{m}^{-1} \text { ] }\right.}\end{array}$ & $\begin{array}{l}\text { Trout parr } \\
{\left[\text { ind. }^{-1} \text { ] }\right.}\end{array}$ & $\begin{array}{l}\text { Egg survival } \\
\text { [average \%] }\end{array}$ & $\begin{array}{l}\text { Spawning area } \\
{\left[\mathrm{m}^{2}\right]}\end{array}$ & $\begin{array}{l}\mathrm{IO}_{2} \\
{\left[\mathrm{mg} \mathrm{l}^{-1}\right]}\end{array}$ & $\begin{array}{l}\mathrm{DG} \\
{[\mathrm{mm}]}\end{array}$ & $\begin{array}{l}\mathrm{PF} \\
{[\%]}\end{array}$ \\
\hline 2020 A2 & 4 & 16 & 83 & 29 & 98.0 & & 14.3 & 28.5 & 2.8 \\
\hline 2020 A3 & 0 & 5 & 68 & 44 & 94.6 & & 13.9 & 33.7 & 0.2 \\
\hline 2020 A4 & 0 & 22 & 40 & 90 & 88.1 & & 14.3 & 41.4 & 0.04 \\
\hline 2020 A5 & 0 & 10 & 60 & 48 & 86.4 & & 14 & 32.6 & 0.04 \\
\hline 2020 A6 & 0 & 0 & 133 & 56 & 95.3 & & 14 & 41.9 & 0.05 \\
\hline 2020 Matre & & & & & 69.7 & & 11.2 & 15.6 & 6.8 \\
\hline
\end{tabular}

fines. The gravel was spread on six sites ranging from 42 to $336 \mathrm{~m}^{2}$, average area was $171 \mathrm{~m}^{2}$. The energy slopes at the sites were between 0.002 and 0.005 .

In Matreelva, $80 \mathrm{~m}^{3}$ of spawning gravel with a $\mathrm{Dg}$ of $32 \mathrm{~mm}$ no fines were added in 2002 using an excavator and a dumper. The area covered was initially $271 \mathrm{~m}^{2}$. Energy slope of the reach measured over $100 \mathrm{~m}$ in length was 0.002 . The hydraulic profile was narrowed from approximately $41 \mathrm{~m}$ to $29 \mathrm{~m}$ at median flow by constructing a groin to increase flow velocities to at least $0.3 \mathrm{~m} \mathrm{~s}^{-1}$ on the spawning gravel.

In Flekkeelva, $70 \mathrm{~m}^{3}$ of spawning gravel with a $\mathrm{Dg}$ of $37 \mathrm{~mm}$ and no fines were added in 2005 using an excavator and a dumper. The area covered was initially $500 \mathrm{~m}^{2}$. Energy slope of the reach measured over $100 \mathrm{~m}$ length was 0.001 (lake outlet).

\section{Costs}

The information about costs for measures in Flekkeelva was documented by Gabrielsen et al. (2007), while the information was provided by the hydropower companies E-Co Energy in Aurlandselva and BKK in Matreelva. The costs include the material and the construction work to conduct the gravel introduction. They do not include costs for planning and monitoring. The costs were adjusted for inflation using the Norwegian Banks online tool (https://www. norges-bank.no/Statistikk/Priskalkulator/) and are presented in 2017 Norwegian krone (NOK, $1 €=10$ NOK April 27th, 2020).

\section{Data analysis}

Changes in sediment characteristics are analyzed by linear regressions $(l m)$ in $\mathrm{R}$ ( $\mathrm{R}$ Core Team, 2018) on $\mathrm{IO}_{2}, \mathrm{Dg}$, spawning area, and fish densities. Juvenile Atlantic salmon and Brown trout densities vary in the three rivers with trout dominating in Aurlandselva and Matreelva and salmon dominating in Flekkeelva. The species have high niche-, habitat-, and behavioral overlap (Jonsson \& Jonsson, 2011), especially in their spawning habitat (Louhi et al., 2008). Thus, the sum of the juvenile densities of both species was chosen to evaluate the development, and the densities of both species were pooled in the regression analysis, called "Atlantic salmonids" (Foldvik et al., 2017, Pulg et al., 2019). Egg survival was modeled by logistic regression with the $\mathrm{glm}$ function in $\mathrm{R}$ using the proportion of surviving eggs as the dependent variable. Fixed effects

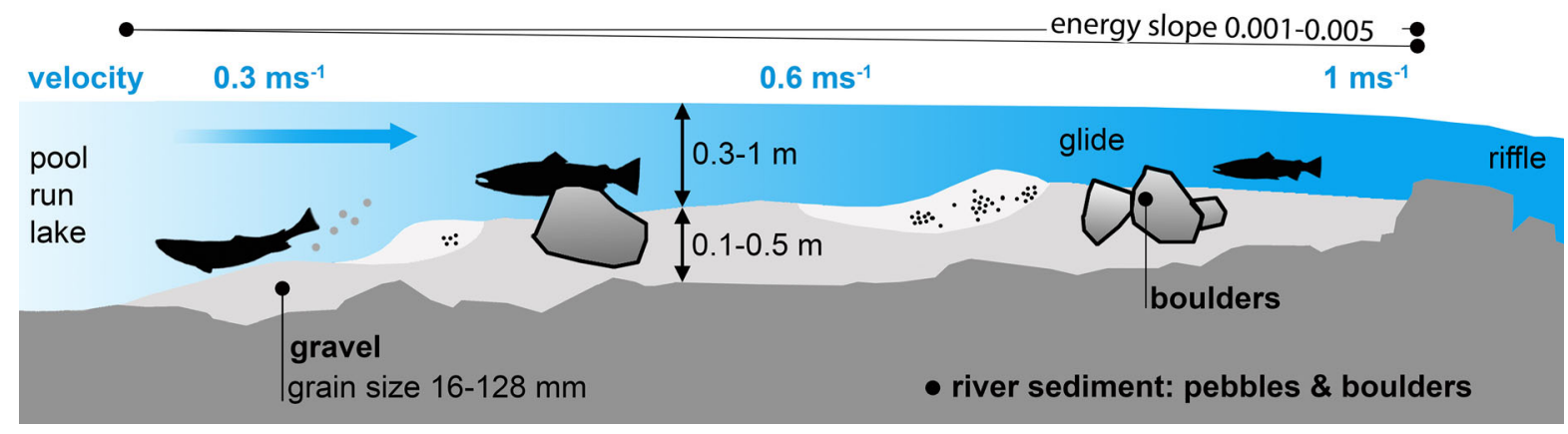

Fig. 4 Design of the spawning gravel augmentations shown as principal longitudinal section at median discharge 
were years since intervention and river. Flekke was excluded because only one egg measurement was made. Density of Atlantic salmonids was modeled by simple linear regression with one model for parr and one for fry using the $\mathrm{lm}$ function in R. Fixed effects were the river (all sites in Aurland were pooled, so this had three levels, Aurland, Flekke, and Matre), life stage (parr or fry), and years since treatment. Years since treatment was preferred to year as a raw numeric to reduce heteroskedasticity.

The regression analysis was conducted for all datasets including more than two sample years. The life span of the gravel additions is evaluated by hydraulics and the flood events that have occurred after gravel augmentation, instead of only relying on simplified models and p-values (Amrhein et al. 2019. Hauer et al. 2020).

\section{Results}

Sediment quality and coverage

$\mathrm{IO}_{2}$ on the gravel sites in Aurlandselva, Matreelva, and Flekkeelva are shown in Figs. 5, 6, and 7 and Table 2. The concentrations were 12.9 to $15.5 \mathrm{mg} \mathrm{l}^{-1}$ (average $14 \mathrm{mg} \mathrm{l}^{-1}$ ), 7.53 to 13.9 (average 11.2) and 9.4 to 14.6 (average 12.8), respectively. The $\mathrm{IO}_{2}$ did not change significantly over time in Aurlandselva $\left(R^{2}=0.08\right.$, $P=0.2$ for $\mathrm{IO}_{2}, \mathrm{DF}=51$ ). There were not enough data points to conduct linear regressions over time in Matreelva and Flekkeelva. At the Matreelva test site, median $\mathrm{IO}_{2}\left(13.2 \mathrm{mg} \mathrm{l}^{-1}\right)$ was approximately the same as in $2002\left(13.1 \mathrm{mg} \mathrm{l}^{-1}\right)$ but reached the lowest individual data point $\left(5.1 \mathrm{mg} \mathrm{l}^{-1}\right)$. At the Flekkeelva test site $\mathrm{IO}_{2}$ was $13.7 \mathrm{mg} \mathrm{l}^{-1}$ in 2018. Both in Aurlands-, Matre- and Flekkeelva median $\mathrm{IO}_{2}$ indicated good incubation conditions after Pulg et al. (2013).

The sediment composition in the areas with gravel augmentation was relatively stable between 2010 and 2020 in Aurlandselva (Dg $2020=37 \mathrm{~mm}, \mathrm{PF}=0.1$, 2020: $\mathrm{Dg}=35.2 \mathrm{~mm}, \mathrm{PF}=1.1$, Table 2, Fig. 11). In Matreelva, the gravel composition became more finegrained over time $($ Dg $2020=15.6 \mathrm{~mm}, \mathrm{PF}=6,8$, Table 2, Fig. 11). In Flekkeelva, the grain size composition changed very slightly from 2005 to 2018 (Dg $2020=29.6 \mathrm{~mm}, \mathrm{PF}=0.02$, Fig. 11).
The size of the spawning area at the test sites changed over time (Fig. 12, Table 2). In Aurlandselva, the total area of the six sites was reduced significantly $\quad\left(R^{2}=0.88, \quad P<0.01\right.$, $y=-0.044 x+1.0781)$ from $1012 \mathrm{~m}^{2}$ in 2010 to $683 \mathrm{~m}^{2}$ in 2018 . This corresponds to an average reduction of $32.5 \%$, ranging from 2 to $77 \%$ on the 6 different sites $\left(1-259 \mathrm{~m}^{2}\right)$. In Matreelva, $72 \%$ $\left(195 \mathrm{~m}^{2}\right)$ of the original gravel area was left in 2018. In Flekkeelva, the gravel area was reduced by $3 \%$ from $500 \mathrm{~m}^{2}$ in 2005 to $485 \mathrm{~m}^{2}$ in 2018 . In total, the median spawning area was reduced by $26 \%$ on the eight sites. The digging and searching for eggs (see below) revealed that the thickness of the gravel layers still was sufficient for spawning $(>14 \mathrm{~cm})$ at all sites.

Egg survival and juvenile fish densities

All six test sites in Aurlandselva were used by spawning salmonids annually from 2010 to 2020 . At least five redds and egg pockets were found and analyzed at each site, except for site five, which was reduced to only $1 \mathrm{~m}^{2}$ in 2015 (Fig. 12). At this site, only one redd was found per year after. Median egg survival in Aurlandselva was 93\%, on average $85 \%$ (Fig. 8). At the site in Matreelva, more than ten redds were found in each sampling year. Average survival was $91 \%$, median survival $100 \%$ (Fig. 9). The range of survival rates broadened in the last years including lower values, but there was no significant negative trend. The site in Flekkeelva was only sampled in 2018 and seven redds were found. The egg survival values ranged from 80 to $100 \%$, with a median of $100 \%$ and an average of $94 \%$ (Fig. 10). Local anglers had observed spawning and redds on the site every autumn from 2005 to 2007 (Gabrielsen et al., 2007). In total, the eight sites in the three rivers had an average egg survival of $90.2 \%$ after gravel augmentation in all monitored years. There was no temporal change in egg survival $(t=0.715, P=0.47)$, which did not differ between Matre and Aurland $(t=0.17, P=0.87$ ).

Juvenile fish densities increased after the spawning habitats were established (Table 2, Figs. 13 and 14). Average fry densities of Atlantic salmonids on the six sites in Aurlandselva were 38 ind. $\mathrm{m}^{-2}$ in 2010. After the gravel augmentation (2011-2020), average fry densities were 72 ind. $\mathrm{m}^{-2}$. Brown trout dominated the total catch (fry 55\%, parr 30\%), with a smaller abundance of Atlantic salmon (fry 8\%, parr $8 \%$, 


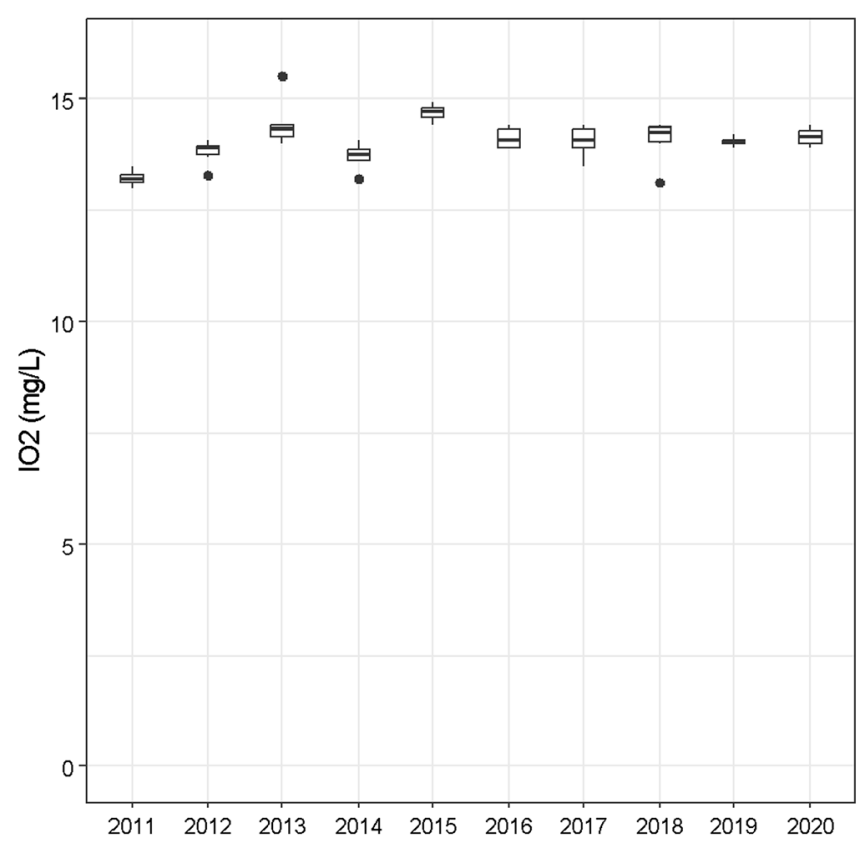

Fig. 5 Interstitial oxygen concentrations in $\mathrm{mg}^{-1}\left(\mathrm{IO}_{2}\right)$ at the test sites in Aurlandselva

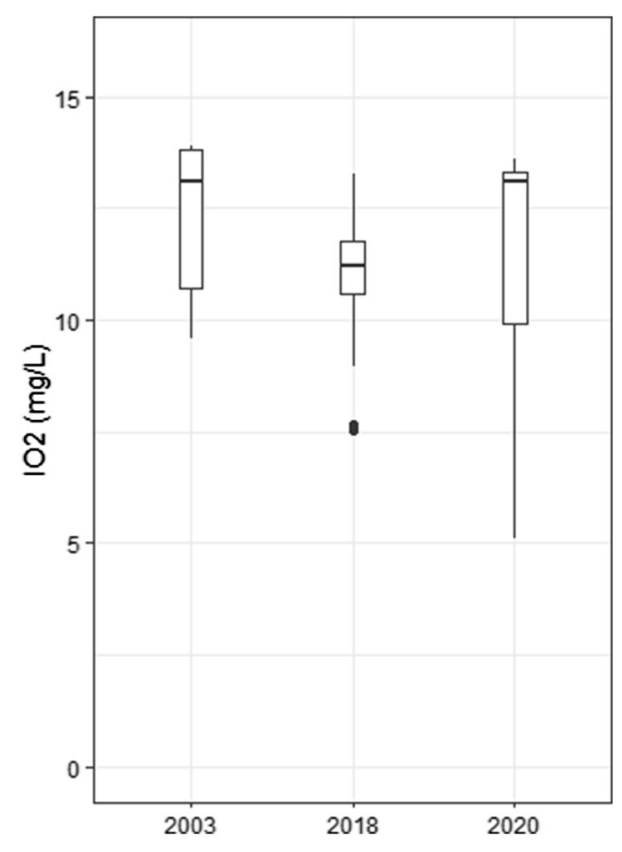

Fig. $6 \mathrm{IO}_{2}$ at the test site in Matreelva

Table 2). At the gravel augmentation site in Matreelva, fry densities of Atlantic salmonids were 6 ind. $\mathrm{m}^{-2}$ in 2002 and 20 ind. $\mathrm{m}^{-2}$ (average) in the years after gravel augmentation. There was a high year to

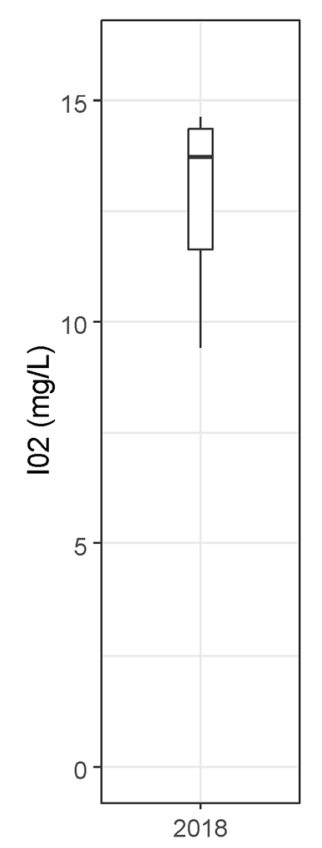

Fig. $7 \mathrm{IO}_{2}$ at the test site in Flekkelva

year variation ranging from 5 to 52 ind. $\mathrm{m}^{-2}$ (Table 2). Brown trout dominated the total catch (trout fry $28 \%$, trout parr 59\%). Salmon fry had a percentage of $4 \%$, salmon parr 9\%. At the test site in Flekkeelva, average 


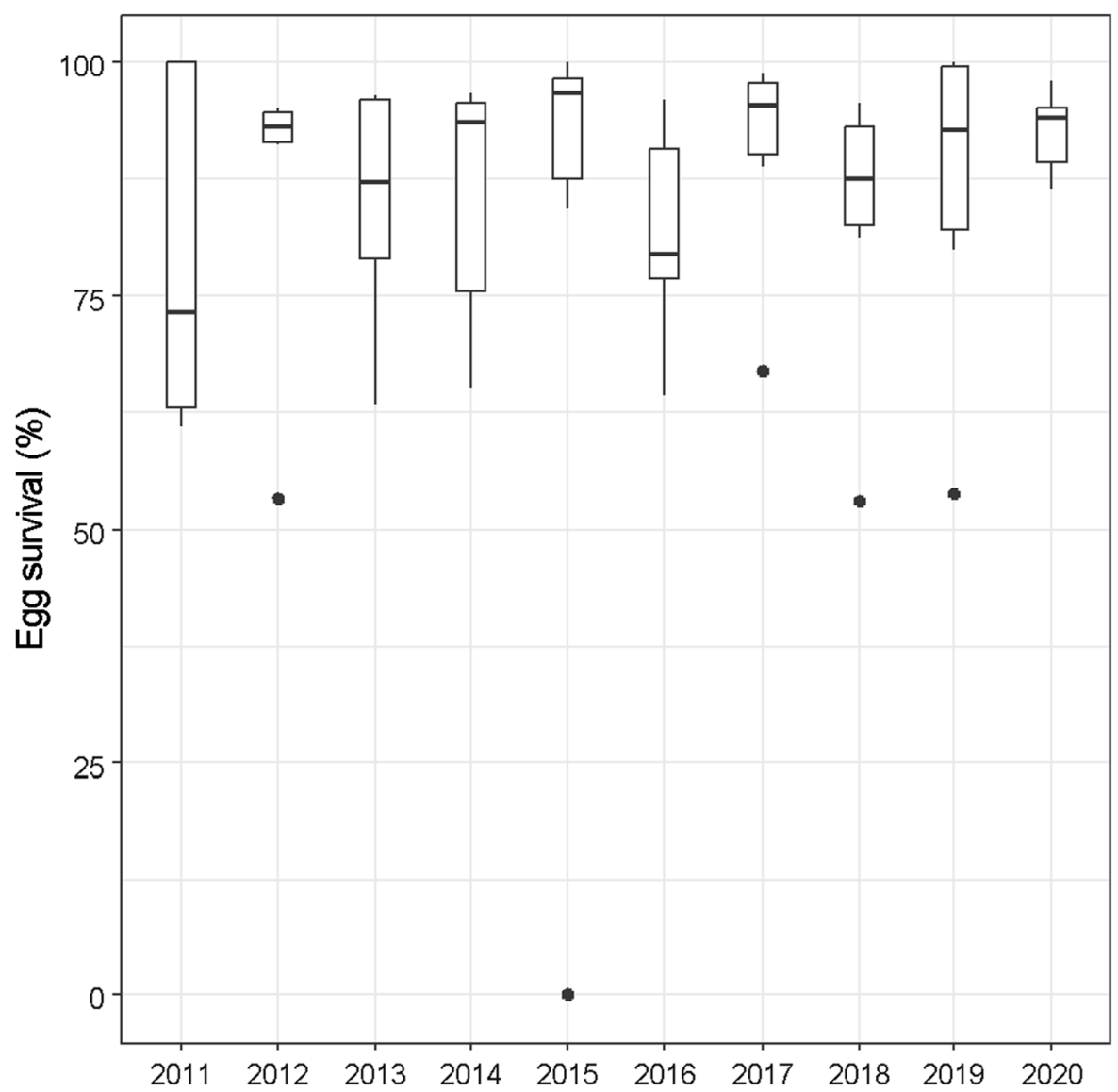

Fig. 8 Egg survival at six test sites in river Aurlandselva

fry densities of Atlantic salmonids were 23.8 ind. $\mathrm{m}^{-2}$ before and 25 ind. $\mathrm{m}^{-2}$ in the years after gravel augmentation. Atlantic salmon dominated the total catch (salmon fry $60 \%$, parr $27 \%$ ) and with a smaller abundance of Brown trout (fry $6 \%$, parr $7 \%$ ). The average total juvenile densities were lower in Flekkeelva (48 ind. $\mathrm{m}^{-2}$ ) than in the other rivers (Aurland 110 ind. $\mathrm{m}^{-2}$, Matre 89 ind. $\mathrm{m}^{-2}$ ). Juvenile densities increased with time after gravel augmentation (fry: $t=2.21, P=0.03$; parr: $t=6.97, P<0.01$ ). Model slopes indicate that fry increased by about 2.04 individuals per $100 \mathrm{~m}^{2}$ per year after gravel augmentation, whereas parr increased by about 4.1 individuals per $100 \mathrm{~m}^{2}$ per year after gravel augmentation. Aurlandselva had higher parr $(t=-2.56, P=0.01)$ and fry $(t=-5.07, P<0.01)$ densities than Matreelva and higher fry densities than Flekkeelva $(t=-2.78, P=0.01)$.

\section{Hydrology}

The average and median discharge in Aurlandselva from 2010 to 2020 were $14.6 \mathrm{~m}^{3} \mathrm{~s}^{-1}$ and $4.1 \mathrm{~m}^{3} \mathrm{~s}^{-1}$, respectively (Table 1 ). The maximum discharge during the period was $141 \mathrm{~m}^{3} \mathrm{~s}^{-1}$ exceeding HQ20. There were three exceeding HQ5, two of these in the year after gravel augmentation. In Matreelva, the average and median discharge between 2002 and 2018 were $3.5 \mathrm{~m}^{3} \mathrm{~s}^{-1}$ and $1.9 \mathrm{~m}^{3} \mathrm{~s}^{-1}$, respectively. Flood events exceeded HQ20 in 2014 and HQ10 in 2018. The average and mean discharge in Flekkeelva between 2005 and 2020 were $22.5 \mathrm{~m}^{3} \mathrm{~s}^{-1}$ and $12.6 \mathrm{~m}^{3} \mathrm{~s}^{-1}$ ,respectively. The maximum discharge during the period was $325.3 \mathrm{~m}^{3} \mathrm{~s}^{-1}$ exceeding HQ10 (Table 1). 


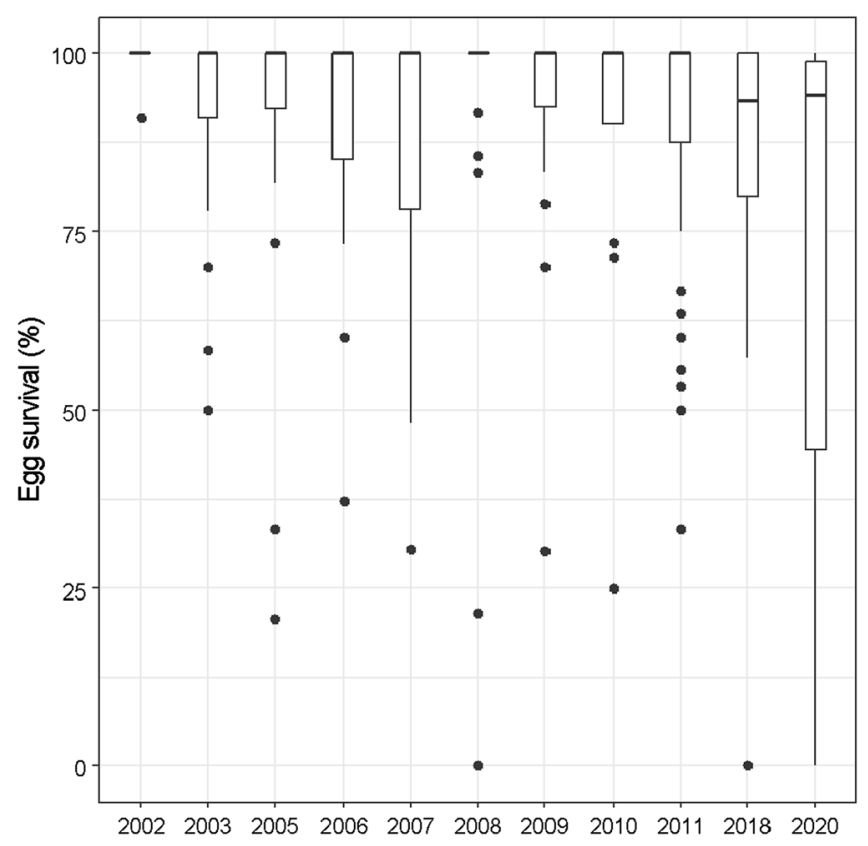

Fig. 9 Egg survival at the test site in Matreelva

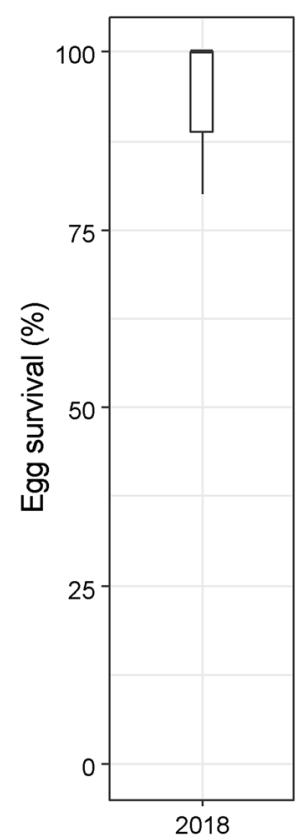

Fig. 10 Egg survival in Flekkelva
Costs

The total construction cost for the six gravel augmentation sites in Aurland was 183,327 NOK (in 2017-NOK, 18,333 €). The costs consisted of gravel transport from the nearby $(1-6 \mathrm{~km})$ gravel pit to the test sites with a dump truck and distributing the gravel by a $22 \mathrm{t}$ excavator in the river. No morphological modifications of the river channel were necessary. Local boulders were placed near- or within the gravel augmentations to increase shelter for spawners.

The total construction cost for the gravel augmentation site in Matreelva was 671,763 NOK (in 2017-NOK, 67,176€). The work consisted of gravel transport from a gravel pit $(50 \mathrm{~km})$ to the chosen sites with a dump truck and distributing the gravel by a $20-\mathrm{t}$ excavator. Extensive morphological modifications (terrain adaptation and groins) were implemented to constrict the water current on the spawning glide.

The total construction cost for the gravel augmentation site in Flekkeelva was 64,107 NOK (in 2017-NOK, 6,411 €). The work consisted of gravel transport from a nearby $(3 \mathrm{~km})$ gravel pit to the augmentation site with a dump truck and distributing 
the gravel by a 20-t excavator. No morphological modifications of the river channel were necessary.

\section{Discussion}

Sediment development

The monitored spawning gravel in Aurlandselva did not degrade by accumulation of fines during the monitoring period. Sediment samples taken after 10 years indicate minor changes of $\mathrm{Dg}$ (from 37 to $35.2 \mathrm{~mm}$ ) and minimal accumulation of fines ( 0 to $1.1 \%$, Fig. 11). The sediment composition is nearly identical over the period, despite a few individual stones $>64 \mathrm{~mm}$ that most likely originate from the natural riverbed and were mixed with the gravel by digging activity of spawning fish. The grain size distributions indicate good reproduction conditions for salmonids (Pulg et al., 2013), which was validated by high egg survival ( $85 \%$ on average) and no declining trend in egg survival (Fig. 8). The size of the augmentation area, however, was reduced significantly, in particular for the site A3 (Fig. 12). This can be explained by scouring during floods. Scouring already occurred during the first 5 years after the gravel augmentation, as described and hydraulically characterized by Hauer et al. (2020). Our data indicate that this process has continued since 2015-but rather linearly than suddenly. The variation in area reduction among the test sites is large, with the site A3 being nearly eroded in 2018 ( $2 \%$ left after 8 years) and site A3 with $78 \%$ of the original area left (value for all sites is $69 \%$, after 8 years Table 2). However, it is important to note that the sedimentological boundaries and morphological framework have an impact on the stability characteristics. Structural features may create favorable flow conditions, like boulders or groins, or shelter against gravel erosion. On the other hand, structural features or rough surface by large grains may increase local turbulence with the consequence of increased scouring (Hauer et al., 2020). Thus, not only are the flood magnitude and forces directly influential, but they also exert secondary influence with respect to how they affect the small-scale flow conditions at the river bottom.

In Matreelva, the accumulation of fines caused a change in the sediment composition during the 15 -year period. Nevertheless, the sediment composition remained within threshold values for good reproduction (Pulg et al., 2013, Dg $>12.9 \mathrm{~mm}$, $\mathrm{PF}<10.3 \%$ ), and the average egg survival remained high at the end of the study (Fig. 8, Table 2). If the accumulation of fines continues, however, the spawning conditions will deteriorate. Fines may originate from the drainage or from autochthonous sediments in the lake outlet, which were observed there before (Gabrielsen et al., 2011). These sediments may have been mobilized and mixed with the added gravel by floods and spawning fishes at the low gradient site (energy slope $=0.002$ ). Similar to Aurlandselva, the size of the spawning area in Matreelva was reduced over time (72\% left after 16 years). The reduction was caused by scouring of gravel from the lower area and growth of the macrophyte Juncus bulbosus L. in the upper area (Velle et al., 2021). The vegetation is likely to baffle the water velocity and contribute to settlement of fine sediments that would otherwise continue

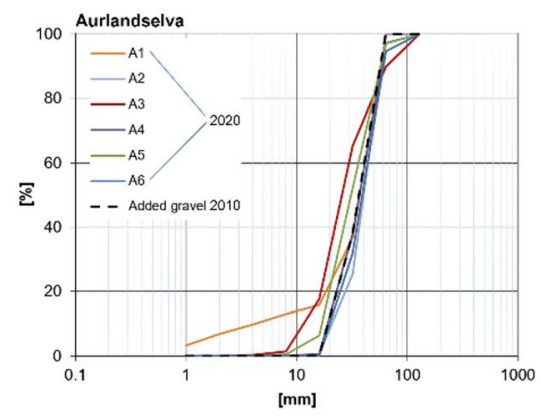

Fig. 11 Grain size distribution curves for the gravel augmentation in Aurlandselva in 2010 and 2020 (left). The average Dg was $35.2 \mathrm{~mm}$ and PF $1.1 \%$ in 2020. Middle: Grain size distribution curves for the gravel augmentation in Matreelva
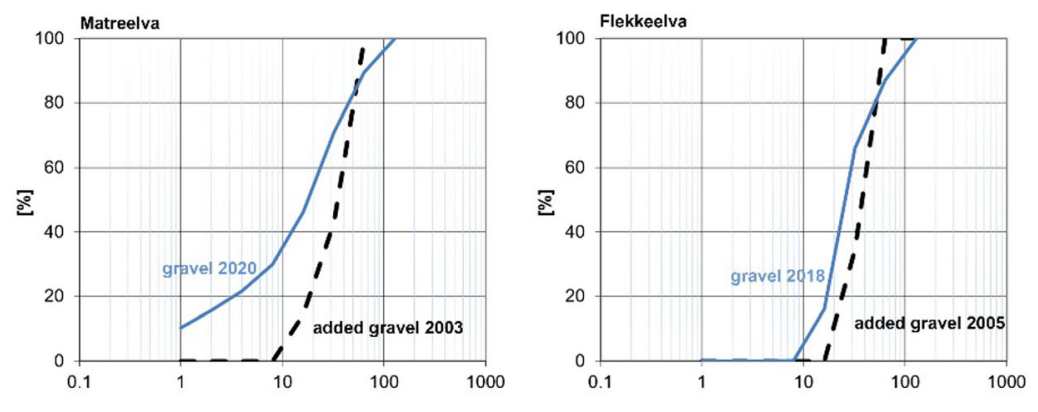

2002 (dashed) and 2020 (blue). Dg was $12 \mathrm{~mm}$ and PF 10.4\% in 2018. Right: Grain size distribution for the gravel augmentation in Flekkeelva in 2005 (dashed) and 2018. Dg was $29.6 \mathrm{~mm}$ and PF $0.02 \%$ in 2018 

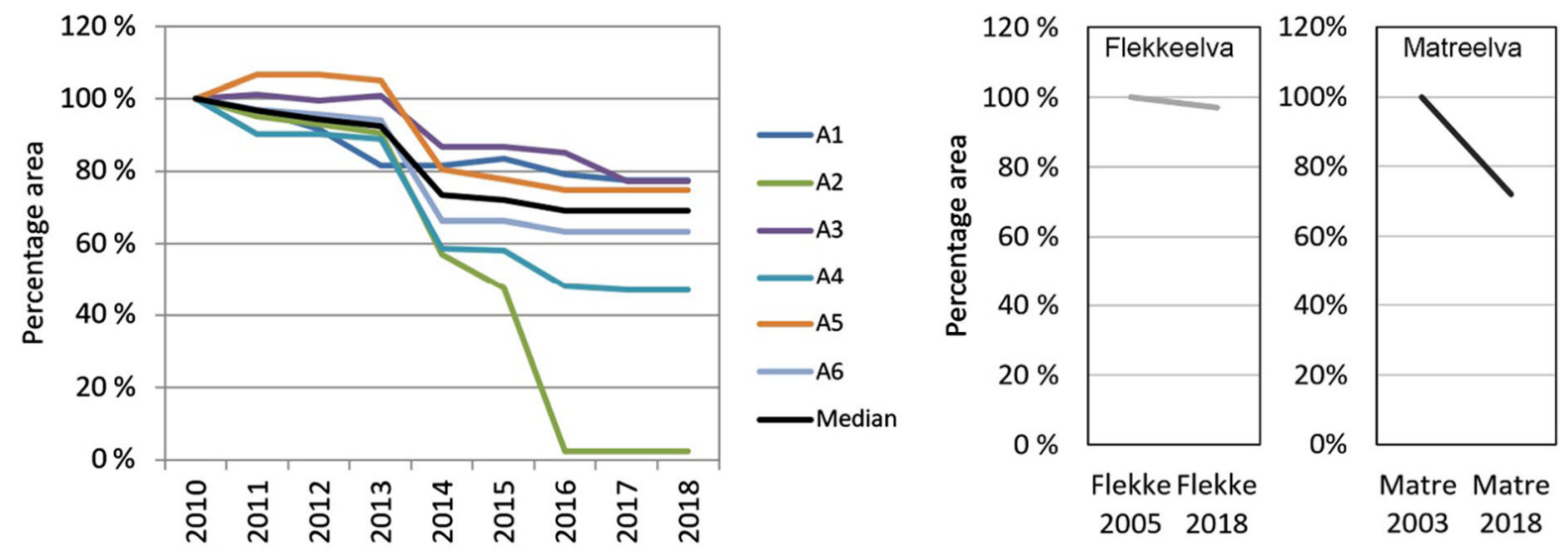

Fig. 12 Percentage of the gravel areas from augmentation to 2018 in Aurlandselva (left), Flekkeelva (middle), and Matreelva (right)

downstream. The limited decrease in the size of the spawning area in Matreelva indicates that the morphological adaptations in the riverbed were well dimensioned and that the placing of the gravel at an energy slope of 0.002 was sufficient.

In Flekkeelva, there were no relevant changes in sediment composition and only minor changes in the size of the augmentation area (97\% of the original site left after 13 years). The large lake directly upstream of the gravel augmentation area functioned as sediment trap for fine sediments. Land use in the drainage area with very limited agriculture, pasture, and foresting is not likely to cause discharge of fine sediments (Opperman et al., 2005; Pulg, 2009). The ratio between $\mathrm{HQm}$ and the average discharge is 14 in Flekkeelva, which is lower than in the other study rivers and may partly explain that the gravel augmentation was intact after 11 annual floods up to HQ10.

Generally, the sediment composition on the eight sites indicates good reproduction conditions for fish in the rivers after 10,13 and 18 monitoring years. Only site A3 in Aurland was nearly scoured after 5 years $\left(8 \mathrm{~m}^{3}\right.$ gravel added, $2 \%$ remaining, energy slope $=$ 0.004). The site was directly downstream a bridge that probably has functioned as a hydraulic constriction during high flows increasing scouring forces. The gravel area at the other test sites were fairly intact (Aurland 69\%, Matre 72\%, Flekke 97\%) and at sufficient thickness (at spawning redds $>14 \mathrm{~cm}$ ). It can be questioned if the results are biased by sampling methods or yearly variation, especially in Flekkeelva with few sampling years. However, because we linked several independent monitoring methods (abiota and biota, sediment, egg survival, juveniles) that all indicate high reproduction success, we conclude that the results reflect good spawning and reproduction conditions throughout. The test sites were not chosen randomly, but with an expectation to still find some gravel left from the oldest augmentations that we are familiar with. Thus, they do not represent a mean of all gravel augmentations measures existing in the region. Hauer et al. (2020) showed that some gravel augmentations sites in Aurlandselva are scoured after only 1 to 2 years. It is therefore concluded that augmentation sites must be chosen carefully after hydraulic- and hydromorphologic suitability under given discharge dynamics, preferably by combining underwater field mapping with hydraulic models. Two dimensional hydraulic models are helpful in fluvial river stretches but are not sufficient to evaluate these criteria on diamictic riverbeds in semi- and non-fluvial reaches, which are typical for post-glacial Western Norwegian rivers (Hauer \& Pulg, 2018; Hauer et al., 2020).

Egg survival and juvenile fish densities

Spawning activity, high egg survival and the significant increase in fry densities after gravel addition, indicate that the measures functioned as intended (Figs. 5, 6, 7, 13, 14). Parr densities increased also significantly, though electrofishing sampling was not primarily designed for parr habitat. The results can be explained by high shelter availability at the shore and partly patchy submersed vegetation at the sites, which is an attractive parr habitat (Foldvik et al., 2017; Pulg et al., 2019; Velle et al., 2021). In Aurlandselva, parr 


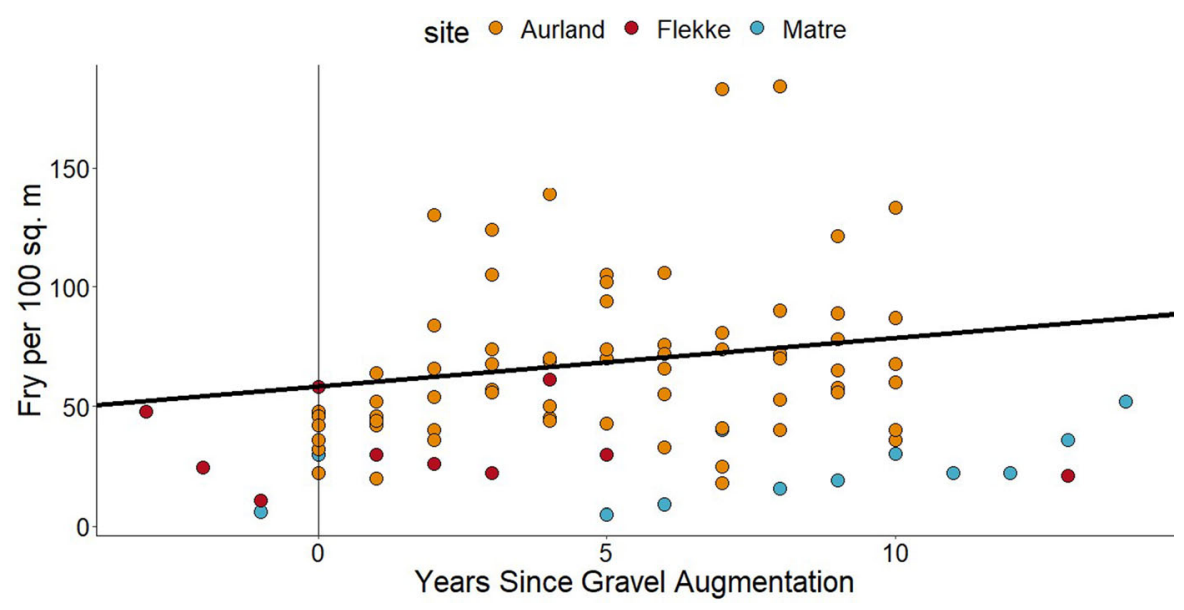

Fig. 13 Atlantic salmon and Brown trout fry densities at the test sites

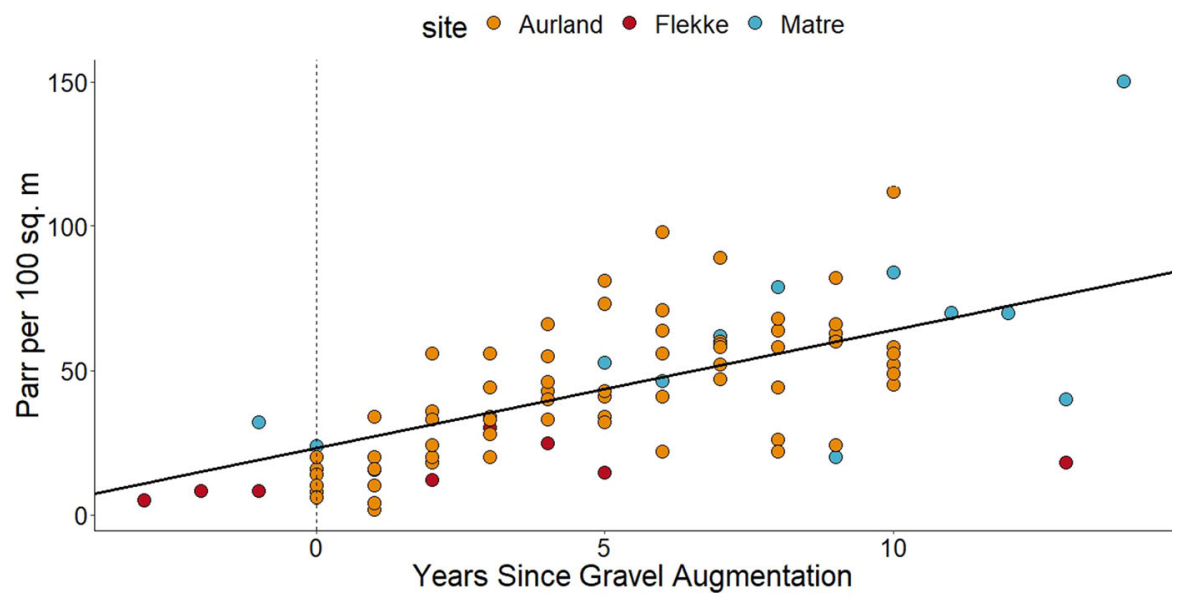

Fig. 14 Atlantic salmon and Brown trout parr densities at the test sites

densities are correlated to fry densities the year before $\left(R^{2}=0.66, P<0.01\right)$ suggesting that the positive effect on fry densities also affects parr densities the year after; a 1-year time dependency indicating temporal autocorrelation. However, autocorrelation functions did not indicate violation of independence so temporal autocorrelation structures were not included. Thus, the results may indicate not only a positive effect on fry but also on parr and thus total juvenile production. Uncertainty and among-year variation in the electrofishing results can be a result of fishing at different conditions (discharge, timing, water temperature, conductivity, substrate type, species and fish length; Scholten, 2003; Hedger et al., 2018) especially in the atypical fry habitat at the lake sites, but it can also reflect natural year to year variation. In regulated
Aurlandselva, the fishing was conducted at approximately the same time, temperature, conductivity, discharge and personnel each year fulfilling the requirements for a robust dataset.

Life span and cost-benefit analysis

Sediment characteristics, egg survival, and fish density indicate functioning of the gravel augmentation measures after 10 years in Aurlandselva, 13 years in Flekkeelva, and 18 years in Matreelva. Average egg survival in Matre was lower in 2020 (70\%) than before, but there wasn't a significant negative trend. The results contrast results on gravel augmentation in other parts of the world where similar measures have had shorter life spans, e.g. ranging from 1 to 6 years 


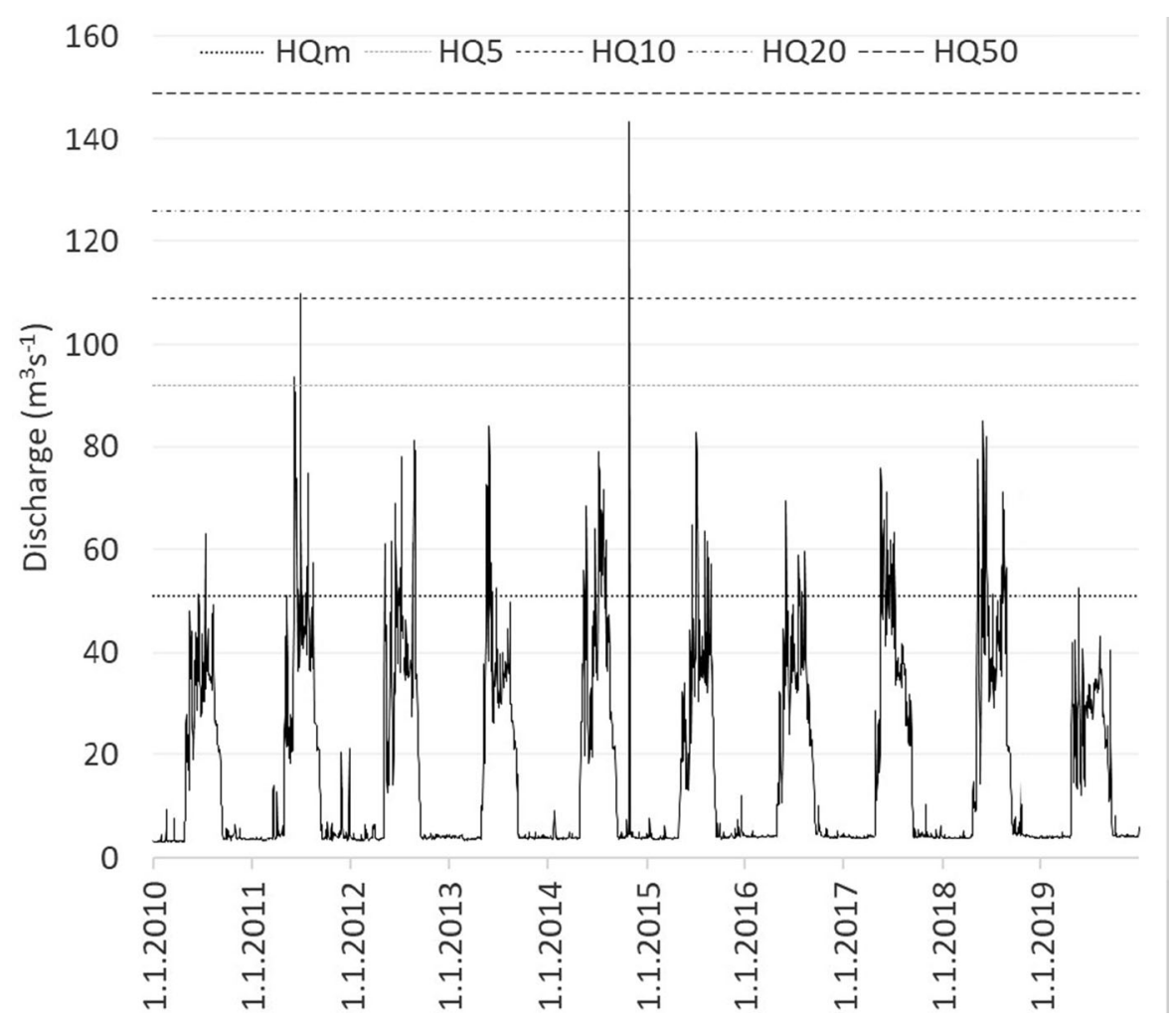

Fig. 15 Discharge curve for Aurlandselva 2010-2020

(Pulg et al., 2013; Pander et al., 2015). Those sites had a higher degree of damming, erosive land use, and higher fine sediment supply (suspended load > $12 \mathrm{mg} \mathrm{l}^{-1}$, Pulg, 2009; Hauer et al., 2013). The longer life span of the studied gravel augmentations in Norway can be explained by the relatively stable morphodynamics due to semi- and non-fluvial geomorphology and low suspended load (Hauer and Pulg, 2020). According to Harrison et al. (2019), the spawning gravel augmentation measure with the longest life span documented so far, was a 14-yearold project for Chinook in Merced River, California. The documented life span of the measure in Matreelva exceeds this period (18 years). The expected life span will probably be even longer because the test sites were still functioning when sampled. A simple linear regression and upscaling suggest that it will take 24 years in Aurlandselva, 54 years in Matreeelva, and 422 years in Flekkeelva until the gravel is completely scoured or overgrown by macrophytes (Matreelva). However, the life expectancy and success of such measures will be affected by irregular events such as large flood events or landslides with fine sediment input as well as gravel moved and transported gradually by spawning fish (Merz et al., 2006; Sear \& DeVries, 2008a; Unfer et al., 2011; Hauer et al., 2018a, b). Lifespan is therefore probably much shorter than the linear upscaling suggests. Based on the flow data and recurrence calculation (Figs. 15, 16, 17) it can be concluded that the measures have tolerated 10 years flood events in Flekkeelva and 20-year flood events in Matre- and Aurlandselva. This would indicate a lifespan of at least 10 years for the site in Flekkelva and 20 years for the sites in Aurlandselva. The observed scouring of gravel, however, has followed a surprisingly linear process (Fig. 12, Aurlandselva), though there were significant flood events in the period (Fig. 15). This can be explained by the choice of locations which aimed at favorable hydraulics. The augmentations were conducted at stretches with the lowest slope available (0.002-0.005) and included stabilizing small-scale features such as boulders (Hauer et al., 2020). Therefore, gravel in Aurlandselva has not been scoured in one event but rather gradually, a process that also may have been influenced by the gradual gravel movement of nest 


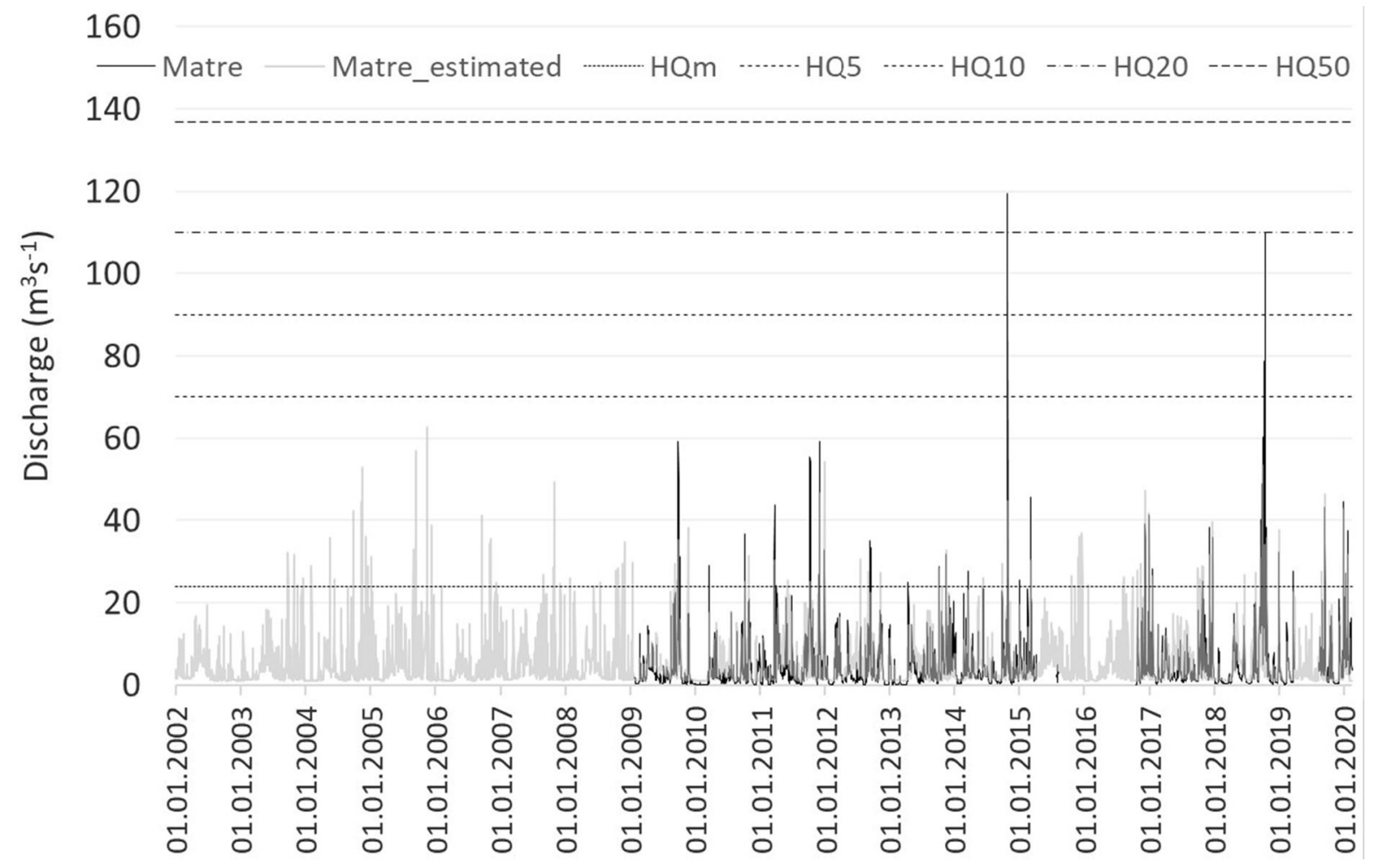

Fig. 16 Discharge curve for Matreelva 2002-2020

building spawners. The sufficient design and placement of the gravel augmentations may also explain why the spawning sites have had a longer life span than similar gravel augmentations in the region that were scoured after the first floods (Barlaup et al., 2008; Hauer et al., 2020).

Many natural gravel spawning habitats in Western Norway are situated on glacial tills or glaciofluvial deposits at lake outlets, e.g. at lake Vassbygdvatnet before regulation (Ugedal et al., 2019), at Lake Eidfjordvannet, Lake Strynsvatnet, Lake Evangervatnet, as observed by Skoglund et al. (2018) during spawner counts. These spawning habitats cannot be supplied by fresh gravel from upstream because the lakes are sediment traps. Our results suggest that such spawning sites nevertheless may function over a long time period since there is no mandatory accumulation of fines at such places in this region of the world (Fig. 11. Flekkeelva). We hypothesize that such lake outlets may have functioned as spawning habitats since their formation after deglaciation 9800-8800 years BP (calibrated), the following bed forming floods during glacier melt (Rye \& Faugli,
1994; Hauer \& Pulg, 2020) and since colonization by gravel bed spawning salmonids (Huitfeld-Kaas 1918). Thus, the sediments on these locations may have served as spawning habitats for more than 8000 years in the semi- and non-fluvial river environment with low suspended load (Hauer \& Pulg, 2018). The cleaning effect of floods and spawning fish was probably enough to maintain good spawning conditions in these lake outlets. In dynamic fluvial gravel bed river reaches spawning habitats may just reach a short life span of a 1-6 years due to morphodynamics, but also because of human-made interference such as increased fine sediment loads and impoundments (Pulg, 2009; Pulg et al., 2013; Pander et al., 2015; Hauer et al., 2018a, b).

Restoring the study rivers including natural fluvial processes such as lateral sediment transport by removing the regulation impacts, as suggested by Beechie et al. (2010), would probably lead to a permanent increase of spawning habitat in the regulated rivers Matre- and Aurlandselva where bank protection and diminished flood discharges have reduced lateral gravel supply. Maintenance or refilling 


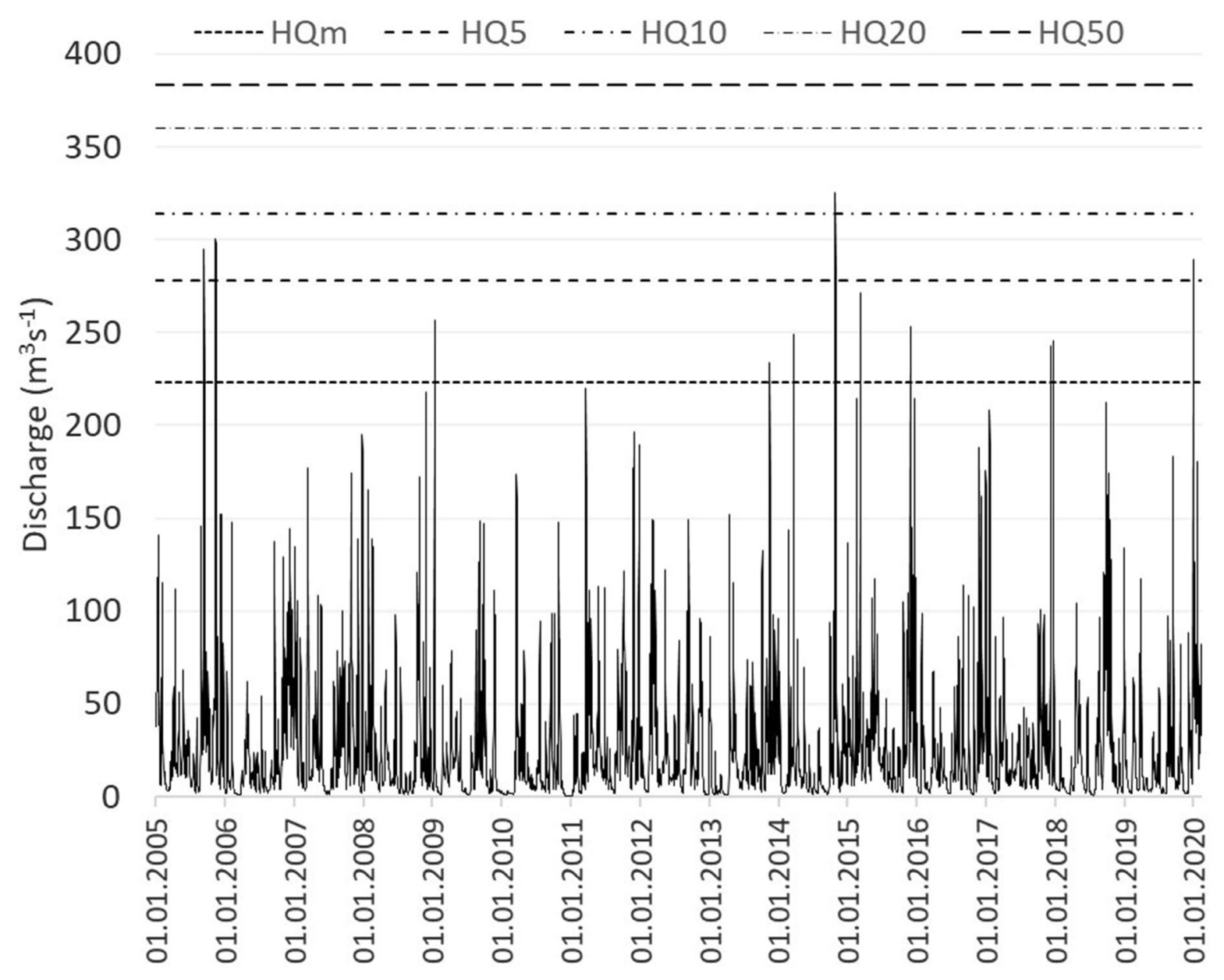

Fig. 17 Discharge curve for Flekkeelva 2005-2020

of gravel is needed when the regulation and river utilization is to persist, as described in the concept of "environmental design" in regulated rivers (Forseth et al., 2014). To provide a permanent high-quality spawning habitat in such a situation, it is necessary to monitor the measures regularly and not to wait until the gravel is scoured heavily. When exactly to replenish gravel is a topic for management targets but has been suggested when ca. $66 \%$ of the original area remains (Ugedal et al., 2019). This takes approximately 10 years in Aurlandselva. It also has to be considered that scoured gravel may accumulate downstream the sites, new spawning habitat may develop there (Merz et al., 2006). In Matreelva, the accumulation of fines may limit the ecological functioning of the spawning habitat in future, but the gravel is still providing good reproduction conditions after
18 years. Further research is needed to see if the sediment composition is getting insufficient or if it will be maintained by spawning fish who clean the substrate for fine sediments and for macrophytes (Velle et al., 2021). The very small accumulation of fines $(0.02 \%)$ and small reduction of spawning area (3\%) at the lake outlet site in Flekkeelva (energy slope 0.001 ) shows that the spawning habitat has functioned well for at least 13 years without maintenance. Fine sediment is trapped in the lake and scouring has not been severe. Since floods have only just exceeded HQ10, further monitoring is needed to measure life span and potential refilling needs.

To conduct a cost-benefit analysis of the gravel augmentations, we suggest dividing the monetary cost of enhancement by the average of gained spawning area and its life span. In Aurland, the measures had an 
average cost of 114 NOK $\mathrm{m}^{-2}$ and functioned for 10 years, thus the costs were $11.4 \mathrm{NOK}(1.14 €) \mathrm{m}^{-2}$ year ${ }^{-1}$ so long. The site in Matreelva had a cost of $2,883 \mathrm{NOK} \mathrm{m}^{-2}$ corresponding to $160 \mathrm{NOK}$ (16€) $\mathrm{m}^{-2}$ year $^{-1}$ (18 years). The site in Flekkeelva had a cost of 130 NOK m ${ }^{-2}$ and 10 NOK $(1 €) \mathrm{m}^{-2}$ year $^{-1}$. On average among the seven pure gravel addition sites in the present study (all despite Matreelva since the costs there included terrain adjustments), the costbenefit was $11.2 \mathrm{NOK}(1.12 €) \mathrm{m}^{-2}$ year $^{-1}$. In the case of longer life spans for the measures, which is likely, these costs will be reduced accordingly. Due to low construction costs and long life span the gravel augmentations on these sites are considered as rather cheap and cost-effective measures. Costs for planning, design and monitoring could not been documented exactly since they were included in larger research projects combined with other tasks. This should be considered when estimating total costs of similar measures, especially since our results suggest that longevity demands proper mapping, choice of placement and design. In retrospective, planning costs were estimated for the 6 sites in Aurlandselva resulting in an estimate of 180.000 NOK $(18,000 €)$, suggesting a doubling of the total costs when including planning in the case $\left(2.28 € \mathrm{~m}^{-2}\right.$ year $^{-1}$, so far). Monitoring of the six sites with the methods chosen are estimated to 130.000 NOK $(13,000 €)$ per season.

The results contribute to fill knowledge gaps identified in the literature on lacking cost-efficiency data of river restoration and habitat enhancement (Roni et al., 2008; Friberg et al., 2016; Louhi et al., 2016; Roni, 2019; Staentzel et al., 2020). Because they are derived from case studies, the results cannot be transferred to other potential gravel augmentation sites. The test sites chosen were not representative for other gravel augmentations and do not reflect an average performance. The results rather show that well-designed gravel augmentations are not necessarily short lived as experienced in several studies in highly impacted rivers (Barlaup et al., 2008; Pander et al., 2015; Roni, 2019), but may function over decades depending on the river type, geomorphology, sediment supply, and river regulation. Our results indicate that low suspended loads and little discharge of fines have contributed to a long life span of spawning gravel augmentations. Other explanations for the observed longevity are the cleaning activity of spawning fish as well as a sufficient choice of gravel placement and design balancing hydraulics over a broad flow range. The results may contribute to a more precise planning and maintenance of gravel bed spawning habitats, which is especially relevant for the implantation of the Water Framework Directive in the Europe, for mitigation measures in regulated rivers, as in the environmental design approach, but also for works in the context of the UN decade of ecosystem restoration and the many other attempts to improve habitat for fish in rivers. Spawning gravel augmentations may not only be considered as habitat enhancement, but may also function as a tool for process-based river restoration in some cases (Beechie et al., 2010; Pulg et al., 2013), for example, at lake outlets where gravel augmentations restore historic glaciofluvial gravel banks and can provide enduring spawning habitats. We recommend further investigations and data collections of such measures including costs to improve the knowledge base and to monitor the measures' total life span.

Acknowledgements We thank the whole staff of NORCE LFI for help during fieldwork and inspiring discussions. This study was financed by the Norwegian Environment Agency (Miljødirektoratet), Norwegian Water Resources and Energy Directorate (NVE), and internal funding program SIS FELT. The monitoring on the sites was financed by E-Co Energi (Aurlandselva), BKK (Matreelva), and the County Governor of Sogn \& Fjordane (Flekkeelva).

Funding Open access funding provided by NORCE Norwegian Research Centre AS.

Open Access This article is licensed under a Creative Commons Attribution 4.0 International License, which permits use, sharing, adaptation, distribution and reproduction in any medium or format, as long as you give appropriate credit to the original author(s) and the source, provide a link to the Creative Commons licence, and indicate if changes were made. The images or other third party material in this article are included in the article's Creative Commons licence, unless indicated otherwise in a credit line to the material. If material is not included in the article's Creative Commons licence and your intended use is not permitted by statutory regulation or exceeds the permitted use, you will need to obtain permission directly from the copyright holder. To view a copy of this licence, visit http://creativecommons.org/licenses/by/4.0/.

\section{References}

Amrhein, V., S. Greenland \& B. McShane, 2019. Scientists rise up against statistical significance. Nature 136: 305-307. 
Barlaup, B. T., S. E. Gabrielsen, H. Skoglund \& T. Wiers, 2008. Addition of spawning gravel - a means to restore spawning habitat of atlantic salmon (Salmo salar L.), and Anadromous and resident brown trout (Salmo trutta L.) in regulated rivers. River Research and Applications 24: 543-550.

Beechie, T. J., D. A. Sear, J. D. Olden, G. R. Pess, J. M. Buffington, H. Moir, P. Roni \& M. M. Pollock, 2010. Processbased principles for restoring river ecosystems. BioScience 60: 209-222.

Bohlin, T., S. Hamrin, T. G. Heggberget, G. Rasmussen \& S. J. Saltveit, 1989. Electrofishing - theory and practice with special emphasis on salmonids. Hydrobiologia 173: 9-43.

Bogen, J. 2015. Map of sediment production in norwegian catchments. https://www.nve.no/vann-og-vassdrag/vannetskretslop/erosjon-og-sedimenttransport/sedimentkilder-ogsedimentbudsjett/. Accessed 13 June 2021.

Foldvik, A., S. Einum, A. G. Finstad \& O. Ugedal, 2017. Linking watershed and microhabitat characteristics: effects on production of Atlantic salmonids (Salmo salar and Salmo trutta). Ecology of Freshwater Fish 26: 260-270.

Forseth, T., A. Harby, O. Ugedal, U. Pulg, H.-P. Fjeldstad, G. Robertsen, B.T. Barlaup, K. Alfredsen, H. Sundt, S.J. Saltveit, H. Skoglund, E. Kvingedal, L. Sundt-Hansen, A. G. Finstad, S. Einum, \& J. V. Arnekleiv. 2014. Handbook of environmental design in regulated salmon rivers. Norwegian Institute for Nature Research. (ISBN 978-82-4262589-2) 90 p. Trondheim.

Friberg, N., N. V. Angelopoulos, A. D. Buijse, I. G. Cowx, J. Kail, T. F. Moe, et al., 2016. Effective river restoration in the 21st century: from trial and error to novel evidencebased approaches. Advances in Ecological Research 55: 535-611.

Gabrielsen, S. E., B.T. Barlaup, H. Skoglund, \& T. Wiers. 2007. Rognplanting, etablering av et nytt gyteområde og gytefisktellinger i Flekke-Guddalsvassdraget -undersøkelser i perioden 2001-2006. NORCE LFI rapport 144. Technical report. Norwegian Research Center, Bergen.

Gabrielsen, S. E., B. T. Barlaup, G. A. Halvorsen, O. R. Sandven, T. Wiers, G. B. Lehmann, H. Skoglund, B. Skår \& K. W. Vollset. 2011. «LIV - Livet i vassdragene »Langsiktige unders $\varnothing$ kelser av laks og aure i Matreelva i perioden 2006-2011. NORCE LFI rapport 187. Technical report. Norwegian Research Center, Bergen.

Greig, S. M., D. A. Sear \& P. A. Carling, 2007. A review of factors influencing the availability of dissolved oxygen to incubating salmonid embryos. Hydrological Processes 21: 323-334.

Harrison, L. R., E. Bray, B. Overstreet, C. J. Legleiter, R. A. Brown, J. E. Merz, R. M. Bond, C. L. Nicol \& T. Dunne, 2019. Physical controls on Salmon Redd site selection in restored reaches of a regulated, Gravel-Bed River. Water Resources Research 55: 8942-8966.

Hauer, C. \& U. Pulg, 2018. The non-fluvial nature of Western Norwegian rivers and the implications for channel patterns and sediment composition. CATENA 171: 83-98.

Hauer, C. \& U. Pulg, 2020. Buried and forgotten - the nonfluvial characteristics of postglacial rivers. River Research and Applications. https://doi.org/10.1002/rra.3596.

Hauer, C., G. Unfer, H. Habersack, U. Pulg \& J. Schnell, 2013. Bedeutung von Flussmorphologie und Sedimenttransport in Bezug auf die Qualitat und Nachhaltigkeit von Kieslaichplatzen. KW-Korrespondenz Wasserwirtschaft 6: 189-197.

Hauer, C., P. Leitner, G. Unfer, U. Pulg, H. Habersack \& W. Graf, 2018a. The role of sediment and sediment dynamics in the aquatic environment. In Schmutz, S. \& J. Sendzimir (eds), Riverine Ecosystem Management - Science for Governing Towards a Sustainable Future. Springer, New York.

Hauer, C., B. Wagner, J. Aigner, P. Holzapfel, P. Flödl, M. Liedermann, M. Tritthart, C. Sindelar, U. Pulg, M. Klösch, M. Haimann, B. O. Donnum, M. Stickler \& H. Habersack, 2018b. State of the art, shortcomings and future challenges for a sustainable sediment management in hydropower: a review. Renewable and Sustainable Energy Reviews 98: 40-55.

Hauer, C., U. Pulg, F. Reisinger \& P. Flödl, 2020. Evolution of artificial spawning sites for Atlantic salmon (Salmo salar) and sea trout (Salmo trutta): field studies and numerical modelling in Aurland, Norway. Hydrobiologia 847: 1139-1158.

Hedger, R. D., O. H. Diserud, O. T. Sandlund, L. Saksgård, O. Ugedal \& G. Bremset, 2018. Bias in estimates of electrofishing capture probability of juvenile Atlantic salmon. Fisheries Research 208: 286-295.

Hendry, K., D. Cragg-Hine, M. O’Grady, H. Sambrook \& A. Stephen, 2003. Management of habitat for rehabilitation and enhancement of salmonid stocks. Fisheries Research 62: 171-192.

Huitfeldt-Kaas, H. 1918. Ferskvandsfiskenes utbredelse og innvandring i Norge med et tillæg om krebsen. - Centraltrykkeriet. Kristiania. $106 \mathrm{~s}$.

Jonsson, B. \& N. Jonsson, 2011. Ecology of Atlantic Salmon and Brown Trout. Habitat as a Template for Life Histories. Springer, New York: 708.

Jonsson, B., N. Jonsson \& O. Ugedal, 2011. Production of juvenile salmonids in small Norwegian streams is affected by agricultural land use. Freshwater Biology 56: 2529-2542.

Jungwirth, M., S. Muhar \& S. Schmutz, 2000. Fundamentals of fish ecological integrity and their relation to the extended serial discontinuity concept. Hydrobiologia 422: 85-97.

Klemetsen, A., P. Amundsen, J. B. Dempson, B. Jonsson, N. Jonsson, M. F. O'Connell \& E. Mortensen, 2003. Atlantic salmon Salmo salar L., brown trout Salmo trutta L. and Arctic charr Salvelinus alpinus (L.): a review of aspects of their life histories. Ecology of Freshwater Fish 12: 1-59.

Knighton, D. 1998. Fluvial forms and processes. A new perspective. Arnold. 382 p.

Louhi, P., A. Mäki-Petäys \& J. Erkinaro, 2008. Spawning habitat of Atlantic salmon and brown trout: general criteria and intragravel factors. River research and applications 24 : 330-339.

Louhi, P., T. Vehanen, A. Huusko, A. Mäki-Petäys \& T. Muotka, 2016. Long-term monitoring reveals the success of salmonid habitat restoration. Canadian Journal of Fisheries and Aquatic Sciences 73: 1733-1741.

Merz, J. E., G. B. Pasternack \& J. M. Wheaton, 2006. Sediment budget for salmonid spawning habitat rehabilitation in a regulated river. Geomorphology 76(1): 207-228. 
Opperman, J. J., K. A. Lohse, N. Colin Brooks, M. Kelly \& A. M. Merenlender, 2005. Influence of land use on fine sediment in salmonid spawning gravels within the Russian River Basin, California. Canadian Journal of Fisheries and Aquatic Sciences 62: 2740-2751.

Pander, J., M. Mueller \& J. Geist, 2015. A comparison of four stream substratum restoration techniques concerning interstitial conditions and downstream effects. River Research and Applications 31: 239-255.

Pedersen, M. L., J. M. Andersen, K. Nielsen \& M. Linnemann, 2007. Restoration of Skjern River and its valley: project description and general ecological changes in the project area. Ecological Engineering 30: 131-144.

Pedersen, M. L., E. A. Kristensen, B. Kronvang \& H. Thodsen, 2009. Ecological effects of re-introduction of salmonid spawning gravel in lowland Danish streams. River Research and Applications 25: 626-638.

Pulg, U. 2009. Laichplätze der Bachforelle (Salmo trutta) in der Moosach - die Bewertung ihrer Funktionsfähigkeit, ihre Degradierung und ihre Restaurierung, Doctoral thesis, Technischen Universität München. https://mediatum.ub. tum.de/doc/680304/680304.pdf.

Pulg, U., B. T. Barlaup, K. Sternecker, L. Trepl \& G. Unfer, 2013. Restoration of spawning habitats of brown trout (Salmo trutta) in a regulated chalk stream. River Research and Applications 29: 172-182.

Pulg, U., K. W. Vollset \& R. J. Lennox, 2019. Linking habitat to density-dependent population regulation: how spawning gravel availability affects abundance of juvenile salmonids (Salmo trutta and Salmo salar) in small streams. Hydrobiologia 841: 13-29.

Roni, P., 2019. Does river restoration increase fish abundance and survival or concentrate fish? The effects of project scale, location, and fish life history. Fisheries 44: 7-19.

Roni, P., K. Hanson \& T. Beechie, 2008. Global review of the physical and biological effectiveness of stream habitat rehabilitation techniques. North American Journal of Fisheries Management 28(3): 856-890.

Rubin, J.-F. \& C. Glimsaeter, 1996. Egg-to-fry survival of the sea trout in some streams of Gotland. Journal of Fish Biology 48: 585-606.

Rye, N. \& P. E. Faugli, 1994. Geology and geomorphology of the Aurland district. Norwegian Journal of Geopgraphy 48: $13-22$.

Scholten, M., 2003. Efficiency of point abundance sampling by electro-fishing modified for short fishes. Journal of Applied Ichthyology 19: 265-277.

Sear, D. A. \& P. DeVries (eds). 2008. Salmonid spawning habitat in rivers: physical controls, biological responses, and approaches to remediation, vol. 65, Bethesda, USA. American Fisheries Society, 376 pp.

Soulsby, C., I. A. Malcolm \& A. F. Youngson, 2001. Hydrochemistry of the hyporheic zone in salmon spawning gravels: a preliminary assessment in a degraded agricultural stream. Regulated Rivers: Research \& Management 17: $651-665$.
Staentzel, C., G. M. Kondolf, L. Schmitt, I. Combroux, A. Barillier \& J.-N. Beisel, 2020. Restoring fluvial forms and processes by gravel augmentation or bank erosion below dams: a systematic review of ecological responses. Science of The Total Environment 706: 135743.

Skoglund, H., T. Wiers, S. E. Nordmann, B. T. Barlaup, G. B. Lehmann, Y. Landro, U. Pulg, G. Velle, S. E. Gabrielsen, \& S. Stranzl, 2018. Gytefisktelling av laks og sjøaure og uttak av rømt oppdrettslaks i elver på Vestlandethøsten 2017. Technical report. Norwegian Research Center LFI rapport nr. 310, p. 33.

R Core Team, 2018. R: a language and environment for statistical computing. R Foundation for Statistical Computing, Vienna, Austria. https://www.R-project.org/.

Terhune, L. D. B. 1958. The Mark VI groundwater standpipe for measuring seepage through Salmon Spawning Gravel. Journal of the Fisheries Research Board of Canada 15: 1027-1063.

Teichert, M. A. K., A. Foldvik, T. Forseth, O. Ugedal, S. Einum, A. G. Finstad, R. Hedger, \& E. Bellier. 2011. Effects of spawning distribution on juvenile Atlantic salmon (Salmo salar) density and growth. Canadian Journal of Fisheries and Aquatic Sciences 68: 43-50.

Ugedal, O., U. Pulg, H. Skoglund, J. Charmasson, E.O. Espedal, J. G. Jensås, S. Stranzl, A. Harby, \& T. Forseth. 2019. Sjøaure og laks i Aurlandsvassdraget 2009-2018. Reguleringseffekter, miljødesign og tiltak. Technical report. NINA Rapport 1716. Norsk institutt for naturforskning.

Unfer, G., C. Hauer \& E. Lautsch, 2011. The influence of hydrology on the recruitment of brown trout in an Alpine river, the Ybbs River, Austria. Ecology of Freshwater Fish 20: 438-448.

Væringstad, T. 2019. Flomberegning for Aurlandselvi (072. Z). Technical report. Oppdragsrapport A nr 2-2019. Norges vassdrags- og energidirektorat. ISBN: 978-82-410-1879-4.

Vannote, R. L., G. Wayne Minshall, K. W. Cummins, J. R. Sedell \& C. E. Cushing, 1980. The river continuum concept. Canadian Journal of Fisheries and Aquatic Sciences 37: 130-137.

Velle, G., Skoglund, H. \& Barlaup, B. T. 2021. Effects of nuisance submerged vegetation on the fauna in Norwegianrivers. Hydrobiologia

Walling, D. E., \& B. Webb, (eds) 1996. Erosion and Sediment Yield: Global and Regional Perspectives: Proceedingsof an International Symposium Held at Exeter, UK, From 15 to 19 July 1996 (No. 236), IAHS.

Wheaton, J. M., G. B. Pasternack \& J. E. Merz, 2004. Spawning habitat rehabilitation - I. Conceptual approach and methods. International Journal of River Basin Management 2: 3-20.

Publisher's Note Springer Nature remains neutral with regard to jurisdictional claims in published maps and institutional affiliations. 